Bulletin of Pharmaceutical Sciences
Assiut University

\title{
BOTANICAL AND BIOLOGICAL STUDY OF THE LEAVES OF CARYOTA MITIS LOUR. FAMILY ARECACEAE CULTIVATED IN EGYPT
}

\author{
Islam A. Abd Elhakim*, Afaf M. Abdel-Baky and D. W. Bishay \\ Department of Pharmacognosy, Faculty of Pharmacy, Assiut University, Assiut, Egypt
}

\begin{abstract}
The macromorphological description of stem, leaves, inflorescences, flowers and fruits in addition to micromorphological study of leaves and primary axis of Caryota mitis lour. Family Arecaceae cultivated in Egypt were carried out for the identification of the plant in both entire and powdered forms. Evaluation of the $L D_{50}$ and pharmacological activities of the dried powdered leaves extracts revealed analgesic, antipyretic in addition to antiinflamatory activities.
\end{abstract}

\section{INTRODUCTION}

The family Arecaceae includes about 181 genera with around 2600 species restricted to tropical and subtropical regions ${ }^{1}$; members of this family are monocot shrubs or palm trees. General features of genus Caryota include that the leaves are bipinnate, very large and primary rachis terminates in a pair of leaflets but individual 2ry axes each terminating in an undivided leaflet ${ }^{2}$. Leaflets are more or less triangular with fish tail appearance and usually with several prominent divergent minor ribs instead of single midrib ${ }^{2}$. The stem is $4-10$ meters in length tufted and more slender in shape and usually present as clusters of stems so called clustering fish tail palm. The fruits of Caryota mitis Lour. are not edible and highly irritant when come in contact with skin due to the presence of acicular crystals of calcium oxalates $^{3}$. Phytochemical screening of genus Caryota revealed that triterpenoids, steroids, flavonoids, alkaloids, saponins, tannins and fatty acids are the chemical constituents present in the plant ${ }^{4}$.

In Folk medicine, it was reported that Caryota mitis is used to stop vomiting and stomach ache ${ }^{5}$, in addition to treatment of constipation, haemorrhoids, loss of virility and rheumatoid arithritis ${ }^{6}$.

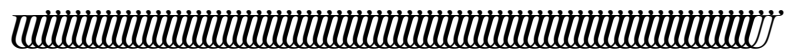

Received in 13/4/2017 \& Accepted in 30/10/2017

\section{Habitat}

Caryota mitis Lour. (Fig. 1) is native to the Southeast Asia, Singapore, India, Thailand, Myanmar and Vietnam, Largely found in tropical and subtropical environments.

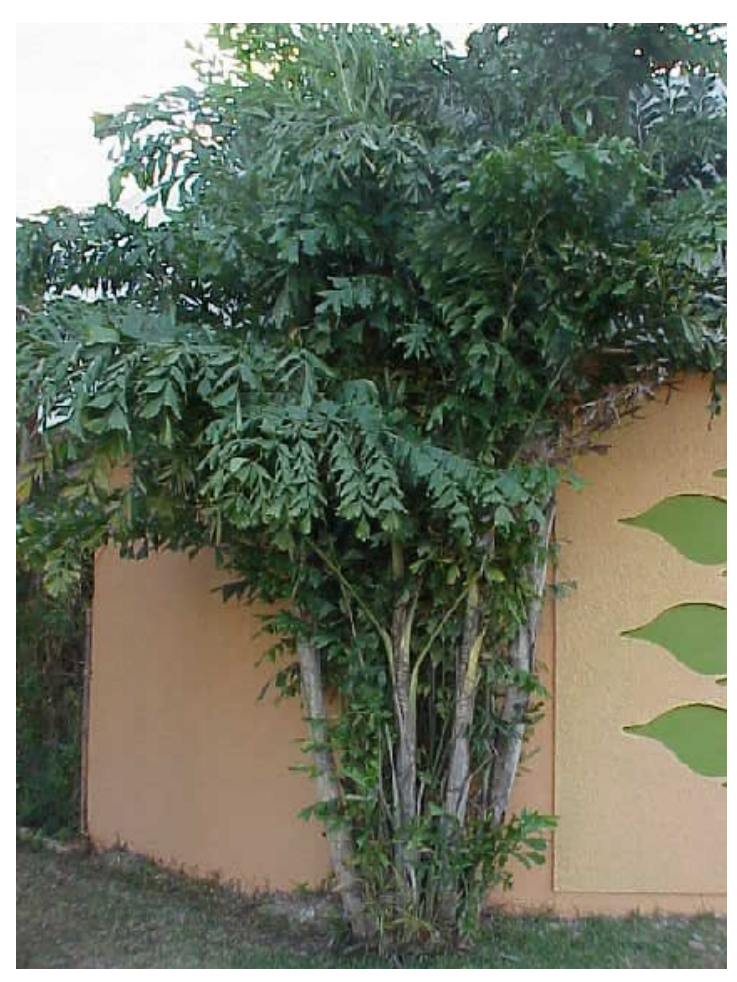

Fig. 1: Photo of Caryota mitis palm. $(\mathrm{X}=1 / 80)$. 


\section{Plant Materials}

Fresh samples of $C$. mitis were collected during the flowering stage on June 2013 from El-Orman Botanical Garden, Giza, Egypt. The plants were kindly identified by Mrs. Traes Labib, general manager and head of specialist for plant taxonomy in El-Orman Botanical Garden, Giza, Egypt. Fresh materials of the separate organs (leaves, primary axis) of $C$. mitis were preserved in mixture of alcohol (70\%): glycerin : water (1:1:1) were used. Each organ was separately air-dried and reduced to a powder of suitable particle size for microscopical examination.

\section{Material for pharmacological screening 1- Plant extract}

The air-dried powdered leaves $(0.5 \mathrm{Kg})$ were extracted with $70 \%$ ethanol till exhaustion. The ethanolic extract was concentrated under reduced pressure to give $60 \mathrm{~g}$ residue which was digested in a least amount of distilled water, transferred to a separating funnel and partitioned with successive portions of $n$-hexane, chloroform, ethyl acetate and n-butanol. These extracts and the aqueous layer left after $n$-butanol were concentrated separately under reduced pressure to yield solvent free residue. Specific weights of the residual extracts were dissolved in $3 \%$ tween 80 in saline solution.

\section{2- Drugs and chemicals}

Tween 80\% (Sigma Chemical Co., St. Louis, USA), normal saline $0.9 \%$ (El-Nasr pharmaceutical and chemical Co., Egypt), indomethacin as standard antipyretic and antiinflammatory drug (El-Nile Co., Egypt), 0.7\% $\mathrm{v} / \mathrm{v}$ acetic acid as pain inducer, $20 \%(\mathrm{w} / \mathrm{v})$ aqueous suspension of yeast as hyperthermia inducer and carrageenan as a factor inducing edema.

\section{3- Experimental animals}

a) Adult male albino rats of $100-120 \mathrm{~g}$ body weight.

b) Adult male albino mice of 25-35 g body weight.

\section{Macromorphology of Caryota mitis Lour 1) The stem}

Caryota mitis palm (Fig. 2) reaches about 4-10 meters height. The plant is typically multistemmed clusters (Fig. 3) in which the stems are erect, cylindrical up to 10 meters height and $5-15 \mathrm{~cm}$ in diameter. The stem is light green at the upper part, while the lower part is greyish or pale brown. Each slender stem is topped with several bipinnate leaves that are born on a primary rachis from which many secondary rachises are formed bearing numerous leaflets. The fibrous leaf bases eventually falling to leave a smooth trunk with distinct internodes. Each trunk produces inflorescences for several seasons, starting from the top of the trunk and moving downwards, but then dies after its final seeding.

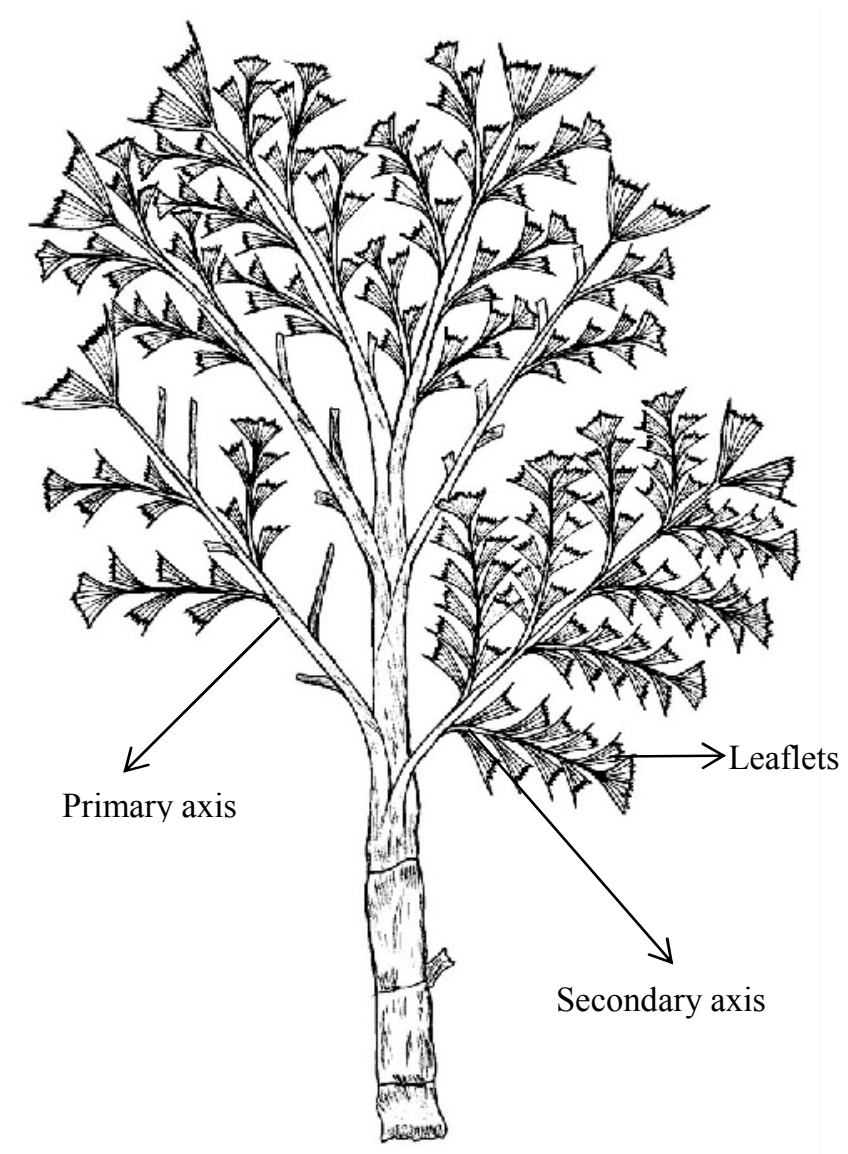

Fig. 2: Macromorphology of the plant. $(X=1 / 40)$. 


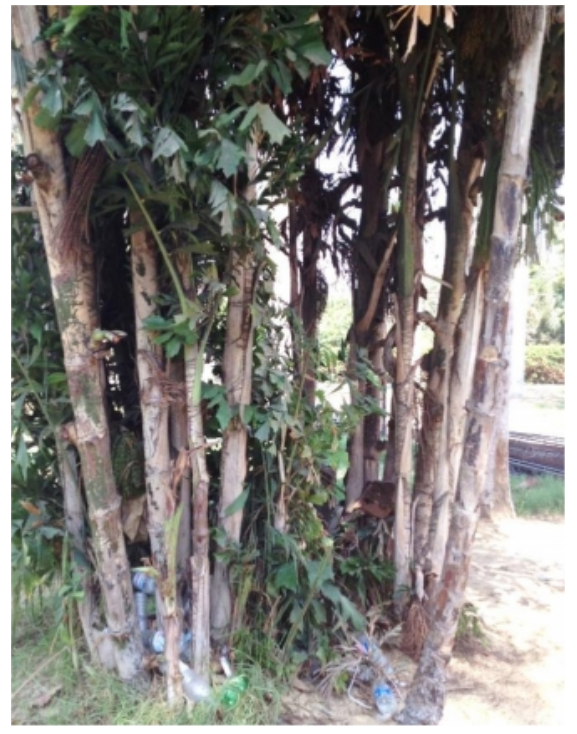

Fig. 3: Photo of clustered stems of C. mitis.

$(X=1 / 25)$.

\section{2) The leaf (Fig. 4)}

The leaves are bipinnate and very large that are borne on a primary rachis or leaf blade up to 3 meters from which secondary axes with 0.4-1.15 meters length originated (Fig. 2). They are green in color, odorless with slightly bitter taste. The primary rachis terminating in a pair of leaflets, but the individual secondary axes each terminating with an undivided leaflet ${ }^{2}$. Leaflets are about 15-35 cm length and 3-20 $\mathrm{cm}$ width, wedge-shaped, like eroded fish tail, with no distinct midrib, but several prominent ribs and the tips broadly toothed. The upper surface is slightly darker than the lower one.

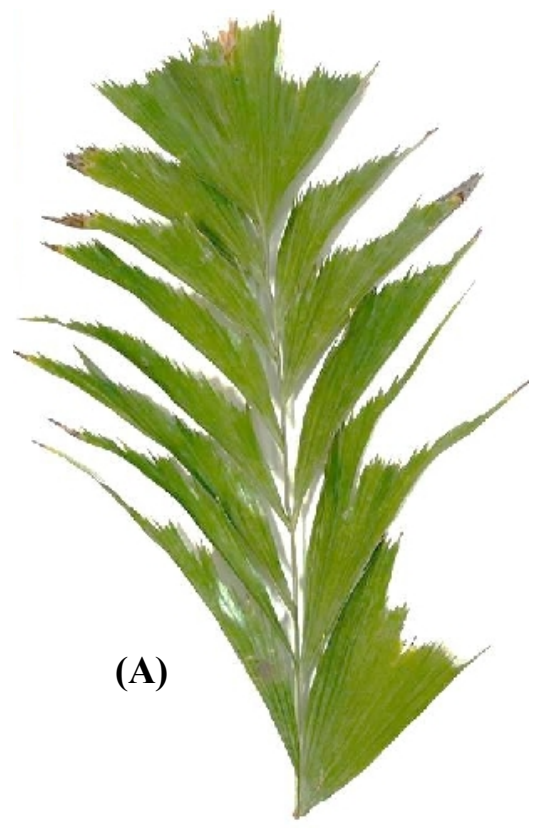

\section{3) The inflorescence (Fig. 5A)}

The plant is monoecious, with basipetal succession in which the flowering proceeds from top of stem to downward. The inflorescence are usually branched that are borne either among or below the leaves, up to $85 \mathrm{~cm}$ length and covered with many persistent bracts. The rachillae are numerous $20-60$ units, long 25-65 $\mathrm{cm}$ and pendulous carrying both male and female flowers ${ }^{7}$ (Fig. 5B \&5C).

\section{4) The flower (Fig. 5D)}

Both male and female flowers are borne on the rachillae of the inflorescence. The flowers are found in threes, two lateral male flowers surrounding one central female flower (Fig. 5C). The flowers are green to yellowish green before expansion, once expanded they become yellowish, purple to maroon in color. The male flowers are $10 \mathrm{~mm}$ in length, having sepals of $3 \mathrm{~mm}$ long, petals of $1-1.5 \mathrm{~cm}$ and about 12-24 stamens. The female flowers are 5 $\mathrm{mm}$ in length, having sepals of $3 \mathrm{~mm}$ length and petals of $4-5 \mathrm{~mm}^{7}$.

\section{5) The fruits (Fig. 5E)}

The fruits are spherical, drupe up to $2 \mathrm{~cm}$ in diameter. The mature fruits are purple to dark red in color containing 1-2 seeds ${ }^{7}$. The fruits of $C$. mitis are not edible and highly irritant even topically due to its contents of numerous acicular calcium oxalates.

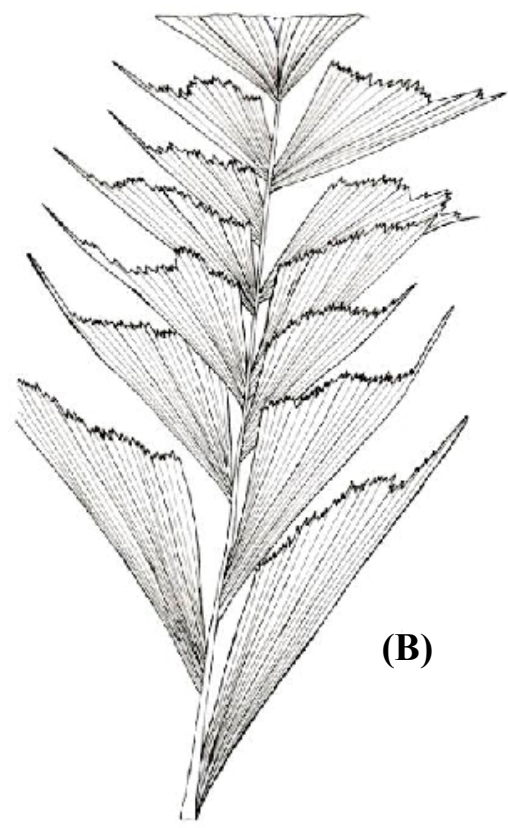

Figs. 4: (A) Photo of the Leaf of Caryotamitis, (B) Macromorphology of the leaf. $\quad(X=0.2)$. 

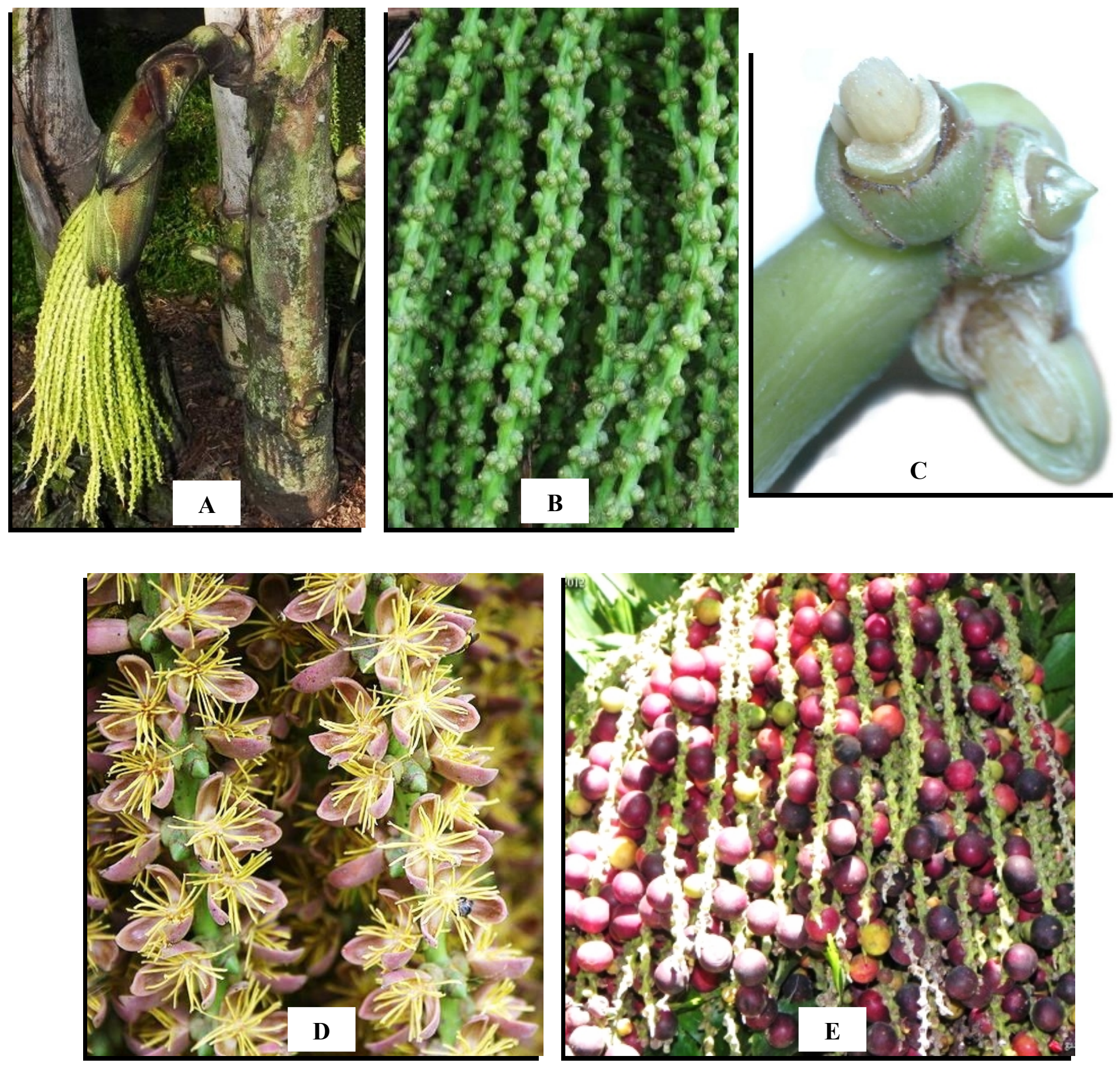

Fig. 5: A-photo of the inflorescence of C. mitis.

$(\mathrm{X}=1 / 15)$

B- Photo of the unexpanded flowers arranged on the rachillae.

$(\mathrm{X}=0.25)$

C- Photo of two lateral male flower surrounding female flower in-between.

$(\mathrm{X}=8)$

D- Photo of the expanded flowers.

$(\mathrm{X}=0.33)$

E- Photo of the ripe fruits.

$(\mathrm{X}=0.125)$ 
II- Micromorphology of Caryota mitis Lour.

1) The leaf (Table 1)

\section{a) The lamina}

Transverse section in the lamina (Figs. 6\&7) showed several small ribs and one large rib which is more prominent in the lower surface. The leaflet is dorsiventral, with one row of columnar palisade cells of variable sizes underlying the upper epidermis containing chloroplasts. Palisade cells are interrupted in the main rib region with a small layer of chlorenchyma followed by a massive sclerotic layer. Mesophyll is parenchymatous, with irregular shaped cells usually polyhedral containing chloroplasts and small closed vascular bundles. Hairs are not observed.
Dumbbell shape stomata are restricted to the lower epidermis, absent in the upper one. The main rib region showed peripheral and central closed vascular bundles, the peripheral ones have massive fibrous sheathes that fused together to form a sclerotic cylinder surrounding the central vascularized parenchyma. The central vascular bundles are scattered each with a fibrous sheath adjacent to phloem only, while xylem sheath is mostly parenchymatous. The ground tissue is parenchymatous, rounded, some cells containing raphides of calcium oxalates, rounded starch granules identified by dilute iodine and some of these cells are pitted.

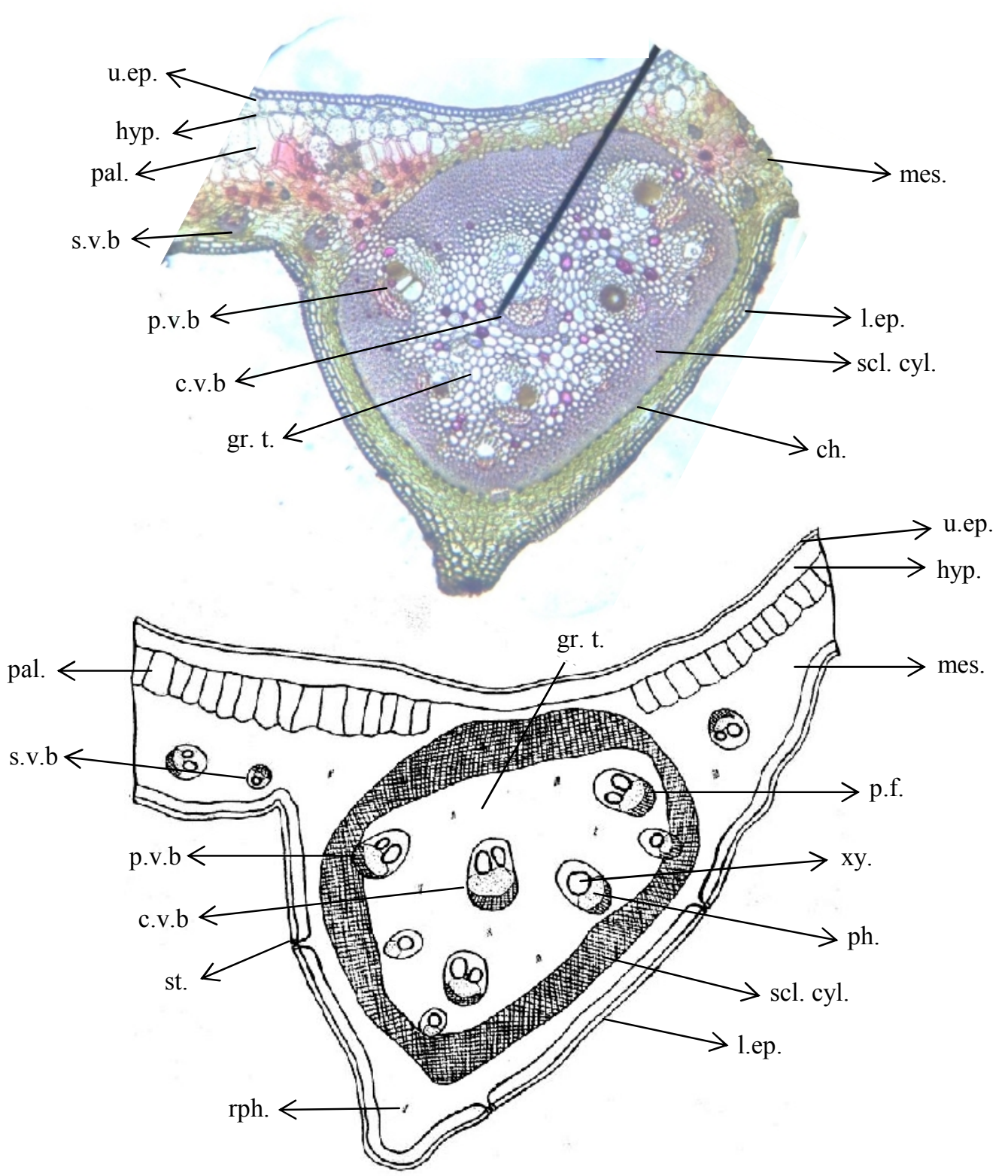

Figs. 6: A- Photo of T.S. in the leaflet. $(X=40)$

B- Diagramatic T.S. in the leaflet. $(X=40)$ c.v.b, central vascular bundle; gr. t., ground tissue; hyp., hypodermis; l.ep., lower epidermis; mes., mesophyll; pal., palisade; ph., phloem; p.f., pericyclic fiber sheath; p.v.b, peripheral vascular bundle; rph., raphides of calcium oxalates; scl. cyl., sclerotic cylinder; s.v.b., small vascular bundle; u.ep., upper epidermis; xy., xylem vessel. 

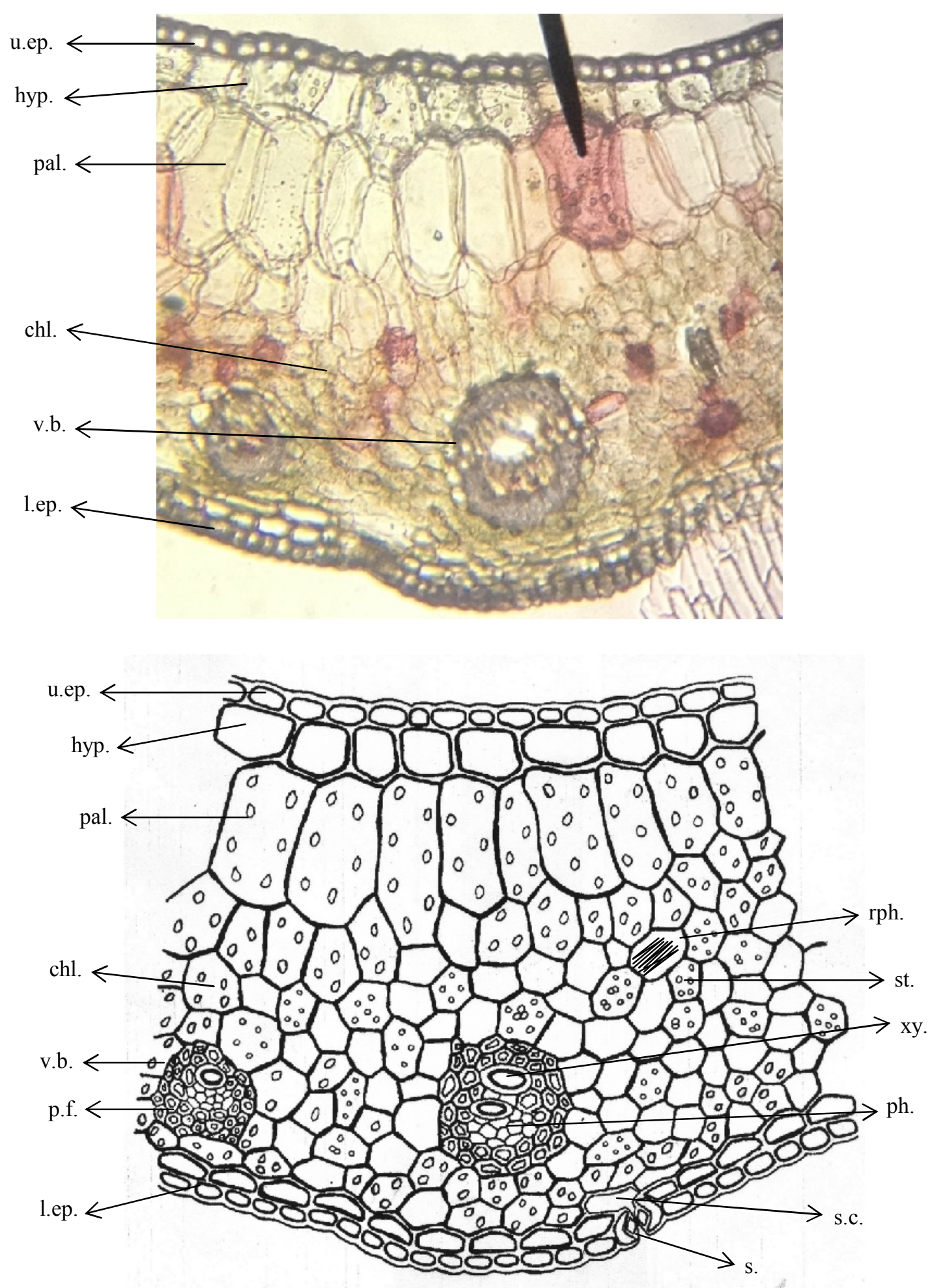

Figs. 7: A- Photo of detailed T.S. in the lamina of leaflet.

$(\mathrm{X}=100)$

B- Detailed T.S. in the lamina of the leaflet.

$(X=100)$

chl., chlorenchyma; hyp., hypodermis; l.ep., lower epidermis; pal., palisade; ph., phloem; p.f., pericyclic fiber; rph., raphides calcium oxalates; s., stomata; s.c., substomatal chamber; st., starch; u.ep., upper epidermis; v.b., vascular bundle; xy., xylem vessel. 


\section{The upper epidermis}

The upper epidermis (Fig. 7A\&7B) consists of one row of square to subrectangular cells as seen in transverse section, while in surface view (Fig. 8); they appear rhombohedral or spindle shape beaded cells, covered with moderately thick smooth cuticle. Stomata are not observed or completely absent.

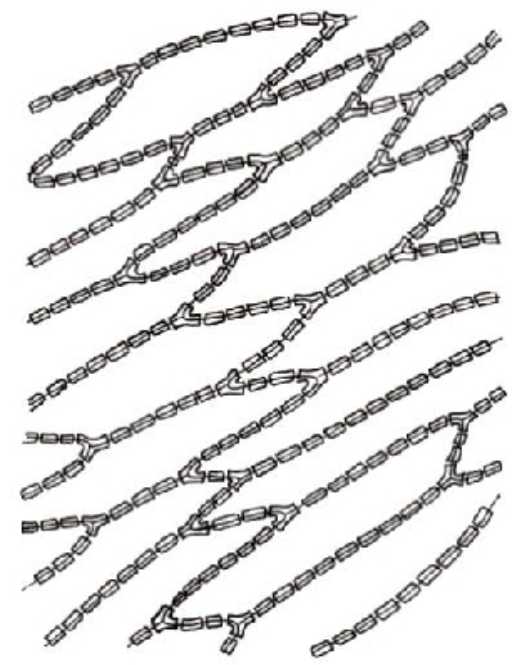

Fig. 8: The upper epidermal cells in surface view.

\section{The lower epidermis}

The lower epidermis (Fig. 7A\&7B) consists of one row of square to cubical cells in transverse section, while in surface view (Fig. 9) they appear rhombohedral, less spindle more regular shape cells, covered with smooth thin cuticle and numerous dumbbell shape stomata are present.

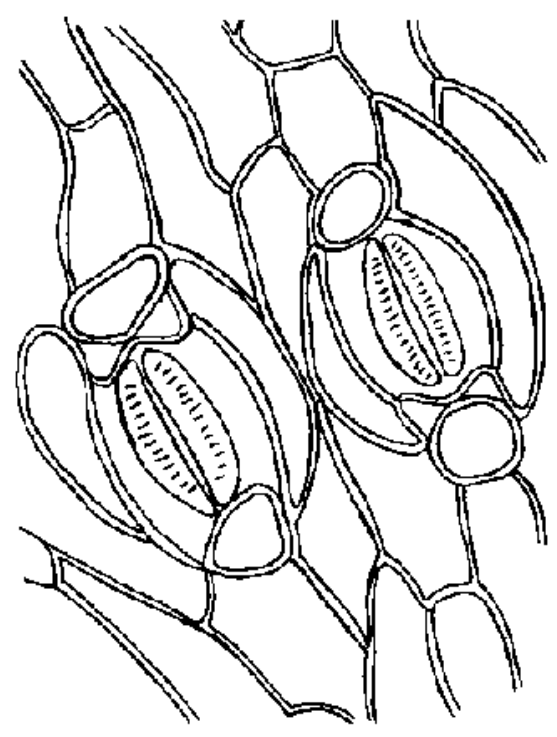

Fig. 9: The lower epidermal cells in surface view.

\section{The Hypodermis}

The hypodermis (Figs. 9,10\&11) is formed of one layer beneath each surface. The upper cells are transversely extended, polygonal in outline. The lower cells are smaller and less regular in shape, without constant arrangement around substomatal chambers ${ }^{2}$.

\section{The mesophyll (Fig. 7)}

The leaflet is dorsiventral showing one layer of palisade underlying the upper epidermis, which is followed by ground tissue with irregular chlorenchyma cells containing chloroplasts. The palisade is formed of one row of cylindrical columnar cells containing chloroplasts. They are interrupted in the central region by a small zone of chlorenchyma cells.

\section{The ground tissue}

The ground tissue of the central region (Figs. 10\&11) consists of oval to rounded parenchyma cells that are surrounded by massive sclerotic zone. Some of these cells are pitted, and some contain raphides of calcium oxalates and rounded starch granules.

\section{Vascular system}

The transverse sector (Figs. 7\&11) showed that the vascular system is of atactostele type with scattered closed vascular bundles. Small vascular bundles are present within the mesophyll. In the main rib region (Fig. 6), peripheral vascular bundles have massive fibrous sheaths that are fused together to form a sclerotic cylinder surrounding the central vascularized parenchyma. Central vascular bundles are scattered each with a fibrous sheath adjacent to phloem only, while xylem sheath is mostly parenchymatous. The xylem consists of one, two or three wide lignified xylem vessels, tracheids and wood parenchyma. The xylem vessels (Figs. 15\&16) showed spiral, sclariform and pitted thickening. The wood parenchyma (Figs. 15\&16) is rectangular to subrectangular cells with thickened lignified walls and numerous pits. The phloem (Figs. 11\&14) is undivided, consists of sieve tubes with compound sieve plates. 


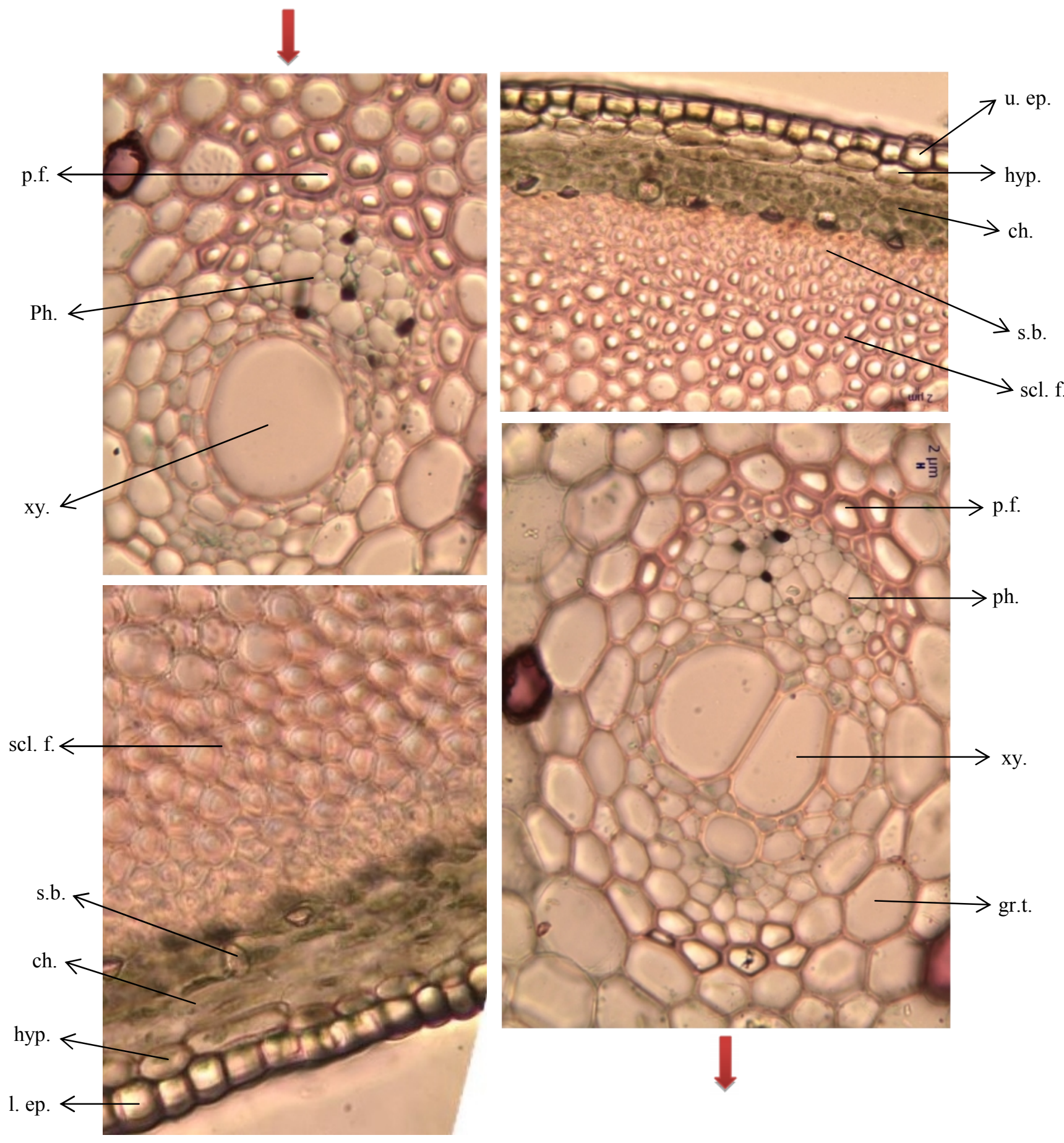

Fig. 10: Photo of detailed T.S. in the main rib of the leaflet.

$(\mathrm{X}=400)$

ch., chlorenchyma; gr.t., ground tissue; hyp., hypodermis; l.ep., lower epidermis; ph., phloem; p.f., pericyclic fibers; s.b., hat shape silica bodies; scl. f., sclrenchymatous fiber; u.ep., upper epidermis; xy., xylem vessel. 


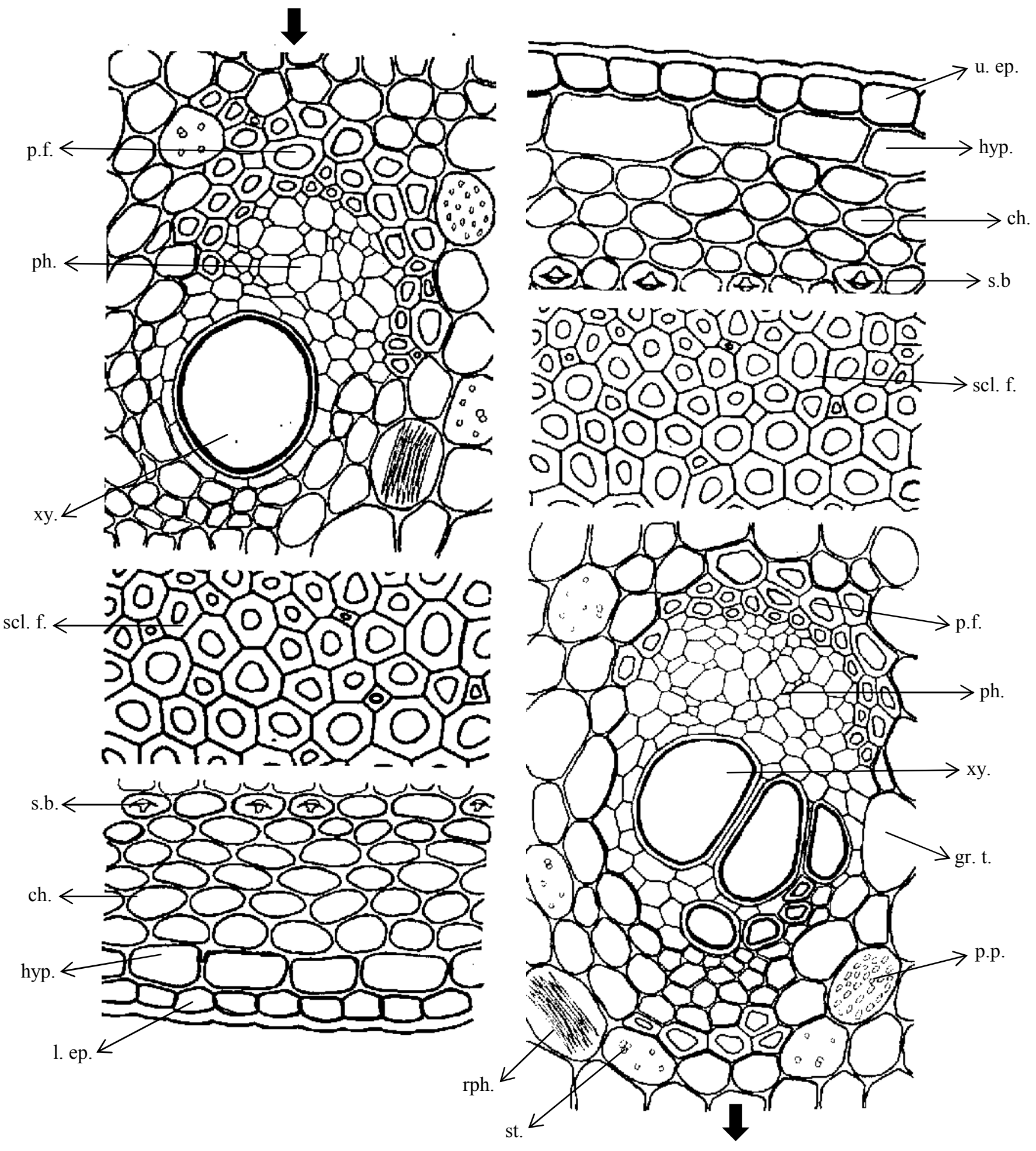

Fig. 11: Detailed T.S. in the main rib of the leaflet.

$(\mathrm{X}=400)$

ch., chlorenchyma; gr.t., ground tissue; hyp., hypodermis; l.ep., lower epidermis; ph., phloem; p.f., pericyclic fibers; p.p., pitted parenchyma; rph., raphides calcium oxalates; s.b., hat shape silica bodies; scl. f., sclrenchymatous fiber; st., starch; u.ep., upper epidermis; xy., xylem vessel. 


\section{b) The secondary axis}

The transverse sector in the secondary axis showed that there are two different shapes (Figs. 12\&13) according to position of cutting either on the top or base of the secondary axis.

The first shape (near the top of axis) is triangular, very similar to the main rib region of the leaflet (Fig. 12A\&12B) in which the epidermal cells are isodiametric without sinuous walls and showing stomata. Hypodermis is one layer usually surrounding continuous narrow layer of chlorenchyma which usually contains numerous raphides of calcium oxalates. Peripheral vascular bundles are with massive sheaths of sclerenchymatous fibers that are fused together to form a continuous sclerotic zone. Central vascular bundles are scattered, each with fibrous sheath adjacent to phloem only while the xylem sheath is mostly parenchymatous.

The second one (base of axis) (Figs. $13 \& 14)$ is somewhat similar to the first shape but no sclerotic cylinder is formed, but massive sclerenchymatous sheathes surrounding the scattered vascular bundles distributed in the ground parenchymatous tissue. Scattered raphides of calcium oxalates and rounded starch granules are distributed within the ground parenchyma.

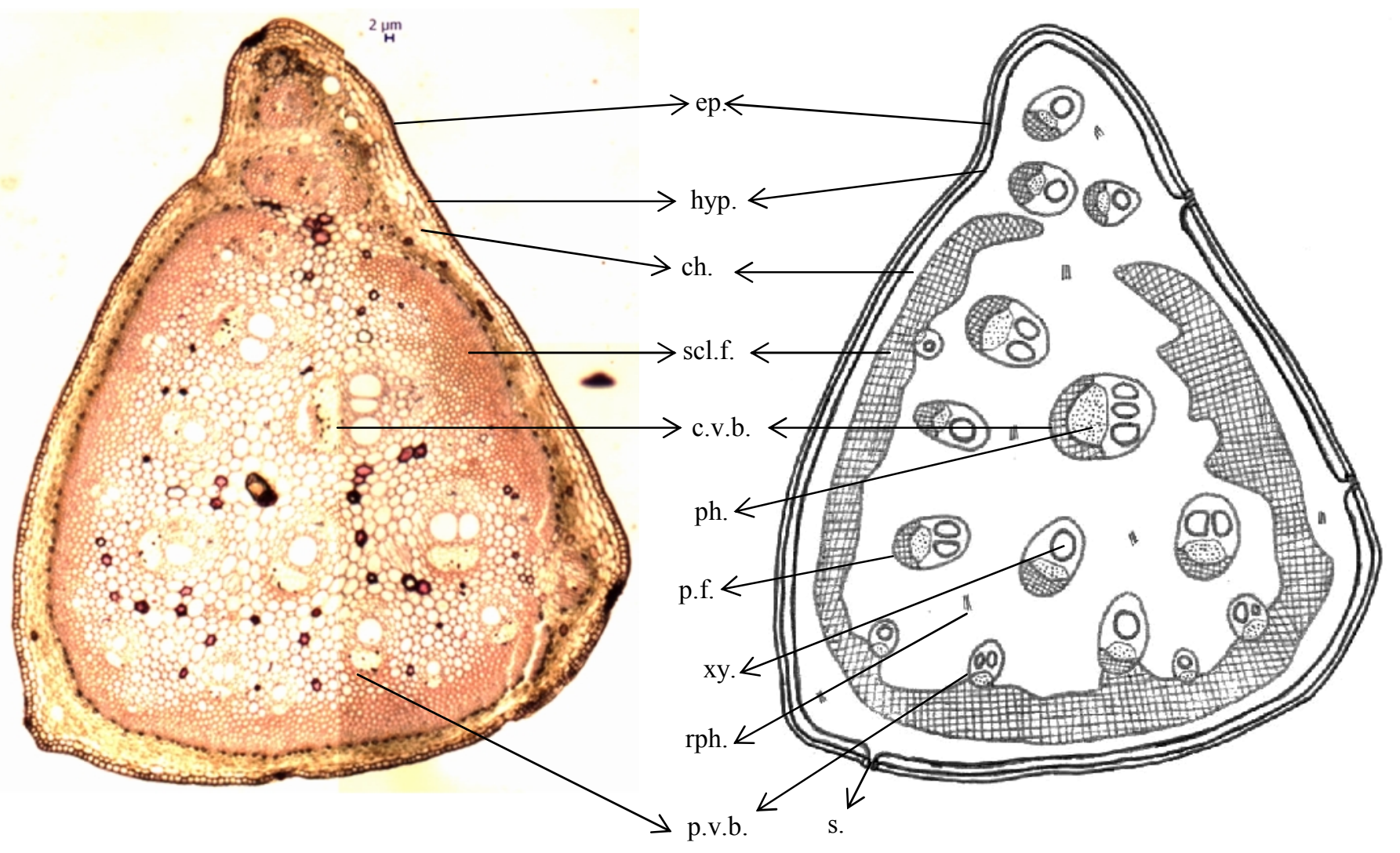

Fig. 12: A- Photo of T.S. diagram in the 2ry axis near the top.

$(\mathrm{X}=200)$

B- T.S. diagram in the 2ry axis near the top.

$(X=200)$

ch., chlorenchyma; c.v.b., central vascular bundle; ep., epidermis; hyp., hypodermis; ph., phloem; p.f., pericyclic fiber; p.v.b., peripheral vascular bundles; rph., raphides of Ca.Ox.; s., stomata; scl. f., sclerenchymatous fibers; st., starch; xy., xylem vessel. 

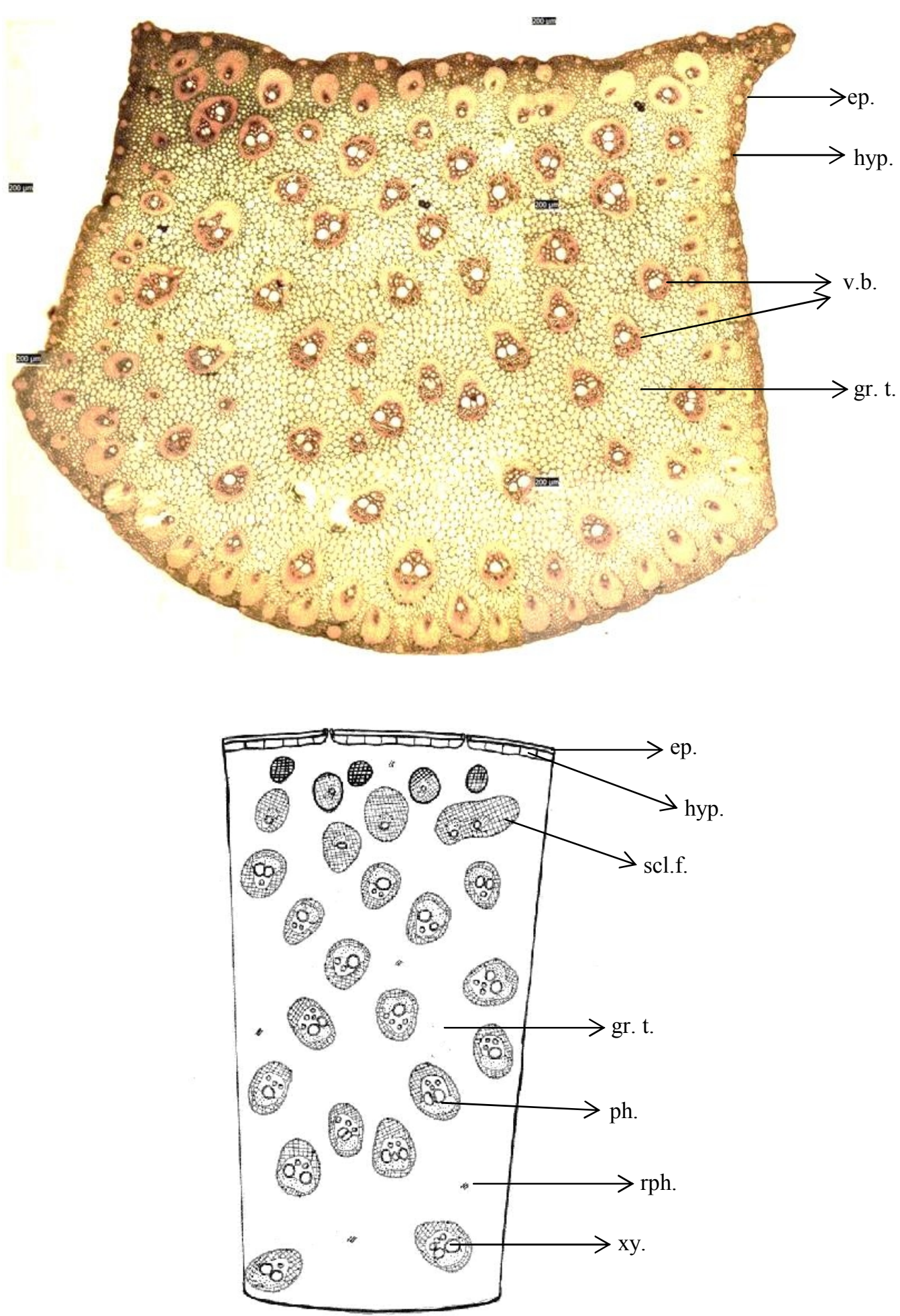

Fig. 13: A- Photo of T.S. diagram in the 2ry axis near the base.

$(\mathrm{X}=40)$

B- T.S. diagram in the 2ry axis near the base.

$(\mathrm{X}=40)$

ep., epidermis; gr. t., ground tissue; hyp., hypodermis; ph., phloem; rph., raphides of Ca.Ox.; scl. f., sclerenchymatous fibers; xy., xylem vessel. 


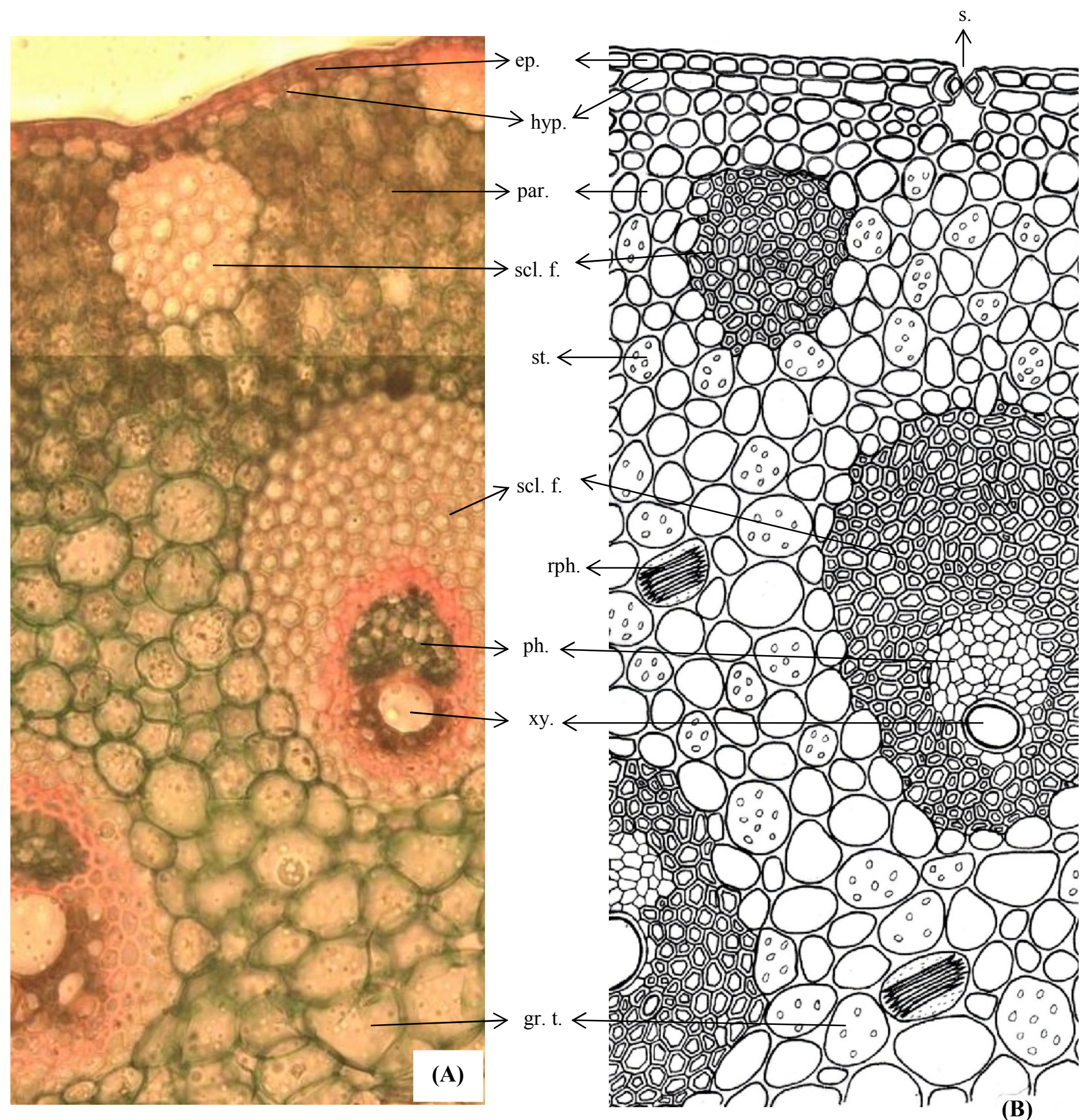

Fig. 14: A- Photo of detailed T.S. in the 2ry axis near the base.

$(\mathrm{X}=200)$

B- Detailed T.S. in the 2ry axis near the base.

$(X=200)$

ep., epidermis; gr. t., ground tissue; hyp., hypodermis; par., parenchyma; ph., phloem; rph., raphides of Ca.Ox.; s., stomata; scl. f., sclerenchymatous fibers; st., starch granules; xy., xylem vessel. 


\section{Powder}

\section{Physical properties}

The powdered leaf is pale green in color, with fibrous touch, faint odor and slightly bitter taste. Microscopical examination of $C$. mitis powder showed the following fragments (Figs. 15\&16):

1- Fragments of the upper epidermis showing rhombohedral or even spindle shaped cells, longitudinally elongated, the cells have thick beaded walls covered with thick smooth cuticle. Stomata and hairs are completely absent.

2- Fragments of the lower epidermal cells that are less spindle and more regular in shape, showing numerous dumbel-shaped stomata, no hairs are observed.

3- Fragments of needle crystals of Ca.ox either free or usually in bundles forming raphides sacs.
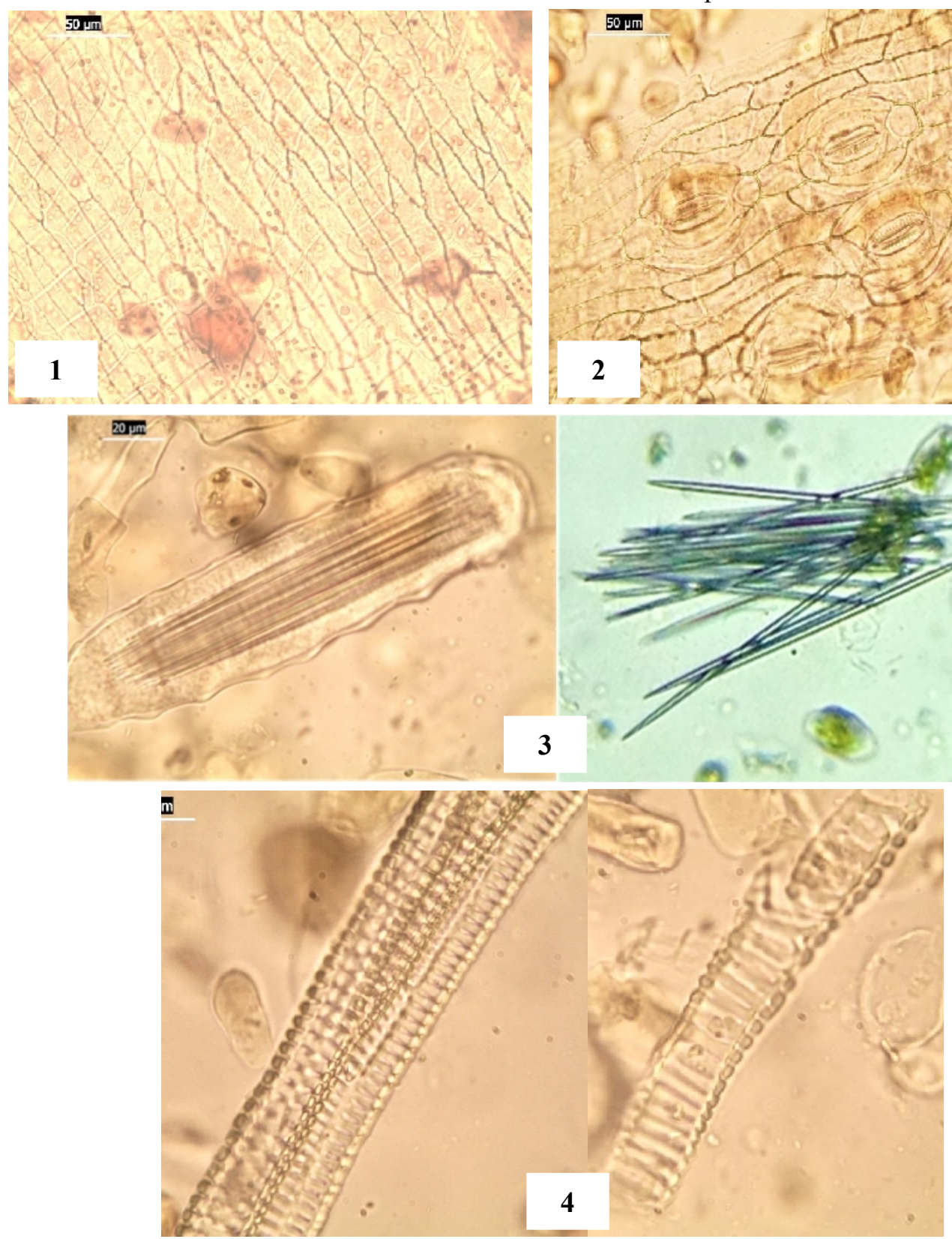

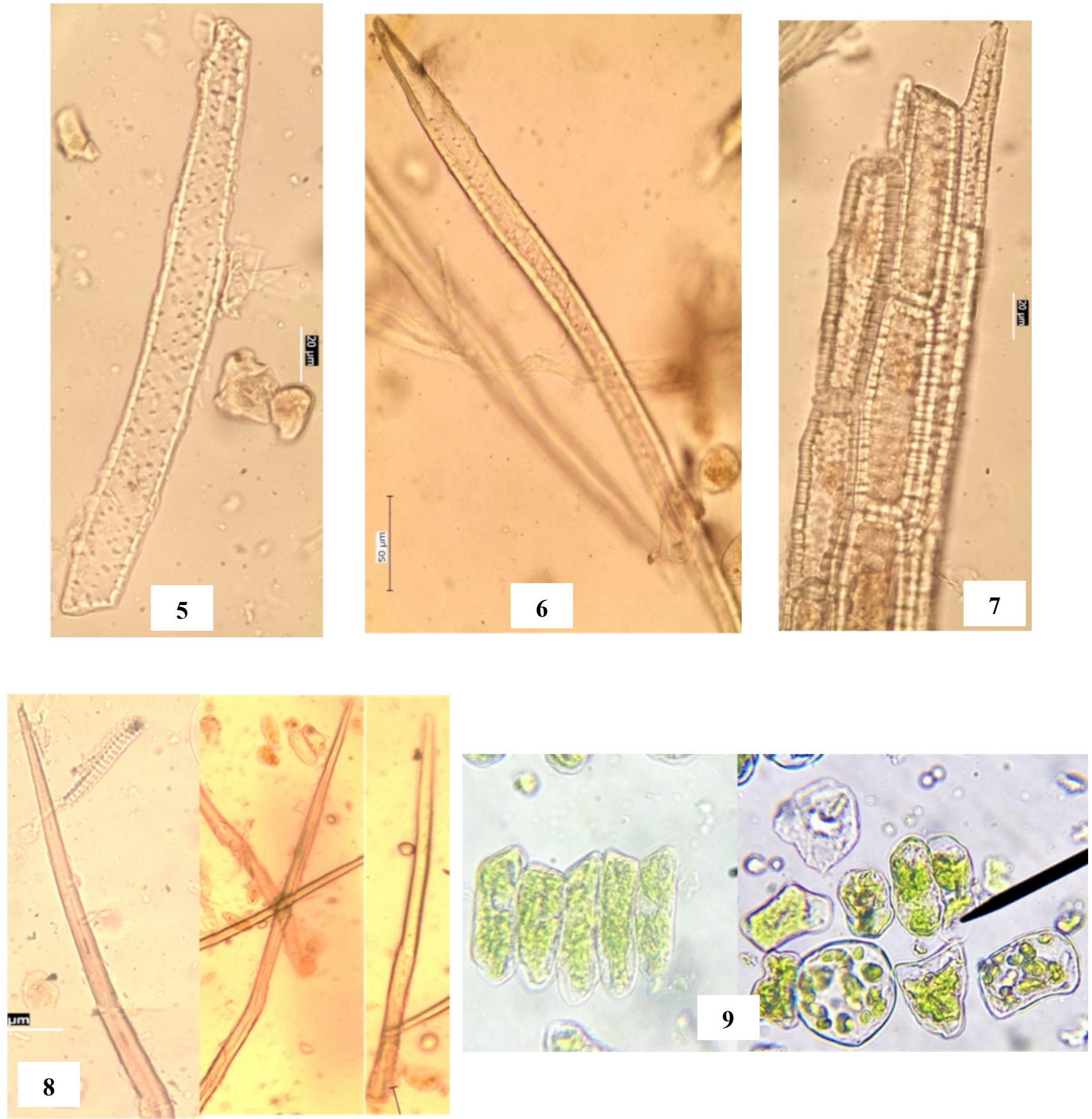

Fig. 15: Photos of the powder and isolated elements of leaf.

$(X=200)$

1, upper epidermis; $\mathbf{2}$, lower epidermis; $\mathbf{3}$, raphides of Ca.Ox; $\mathbf{4}$, xylem vessels; $\mathbf{5}$, tracheid; $\mathbf{6}$, tracheidal fiber; $\mathbf{7}$, wood parenchyma; 8 , pericyclic fibers $(x=400) ; 9$, palisade cells \& parenchyma cells containing starch and chloroplasts. 

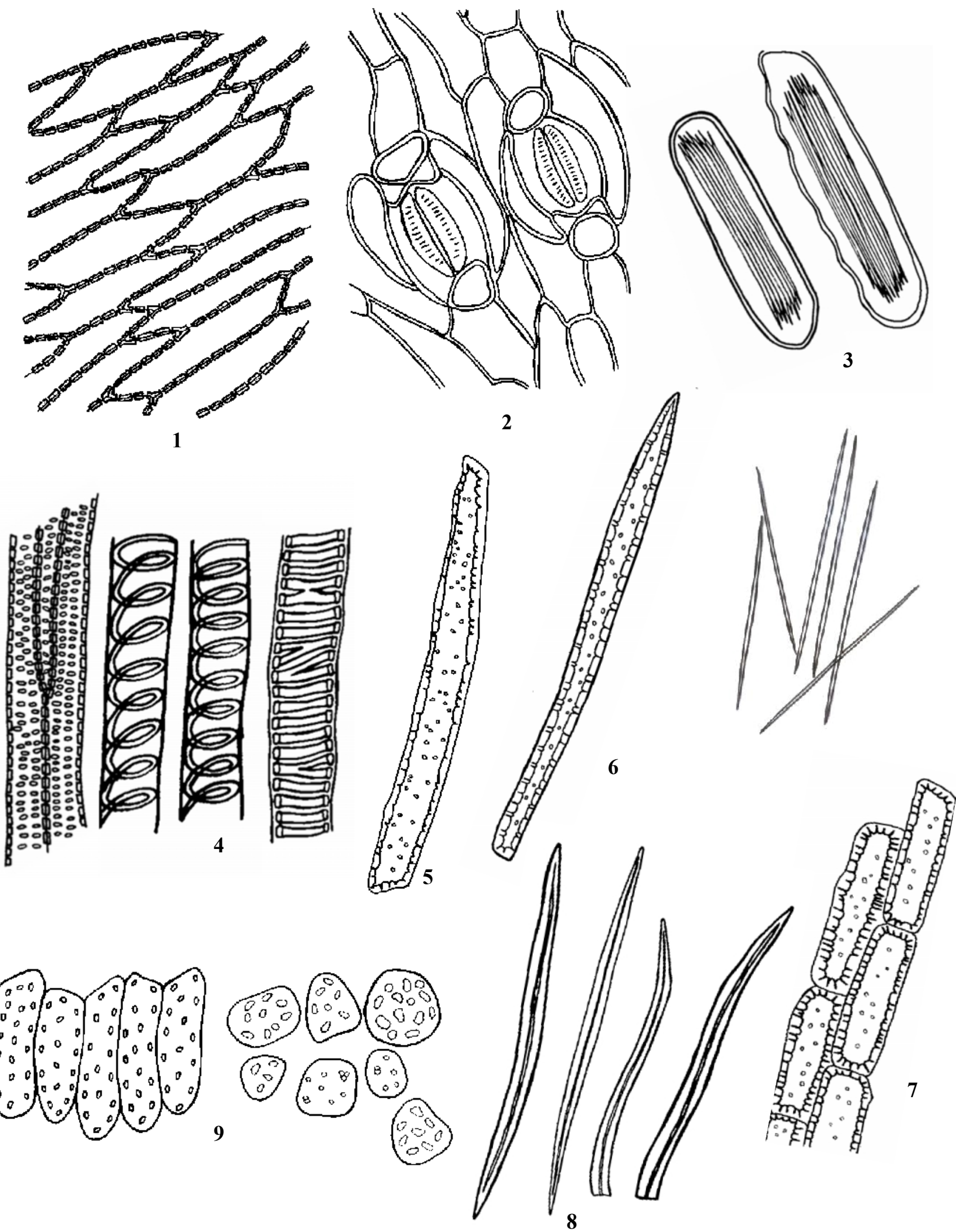

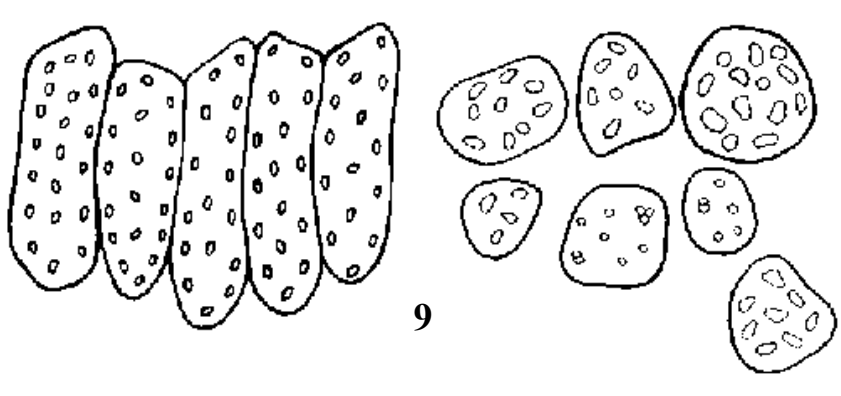

$(X=200)$

Fig. 16: Powder and isolated elements of leaf.

1, upper epidermis; 2, lower epidermis; 3, raphidesof Ca.Ox; 4, xylem vessels; 5, tracheid; 6, tracheidal fiber; 7, wood parenchyma; 8 , pericyclic fibers; $\mathbf{9}$, palisade cells \& parenchyma containing starch. 
Table 1: Microscopical measurements of the leaf of C. mitis Lour. (in microns).

\begin{tabular}{|c|c|c|c|c|}
\hline Item & Length & Width & Diameter & Height \\
\hline \multicolumn{5}{|c|}{ Leaf } \\
\hline Upper epidermis & $59.6-79.2-90.7$ & $11.2-16.6-21.8$ & & $10.2-15.2-20.3$ \\
\hline Lower epidermis & $33.8-81.3-99.6$ & $11-16.1-23.6$ & & $13.1-17.8-22.1$ \\
\hline Hypodermis & & & $24.3-39.7-55.9$ & $13.81-16.7-21.1$ \\
\hline Neural epidermis & $14.5-29.1-39$ & $11.8-16.9-20.6$ & & \\
\hline Stomata & $28.2-34.5-41.3$ & $44.5-51.3-57.7$ & & \\
\hline Palisade cells & $55-90-114$ & $29-43-59$ & & \\
\hline Parenchyma & & & $22.5-31.1-44.7$ & \\
\hline Chlorenchyma & & & $6.3-9.6-13.2$ & \\
\hline Acicular $\mathrm{Ca} \mathrm{Ox}$. & $173-190-223$ & & & \\
\hline Pericyclic fibres & $324-632-854$ & $11.2-14.9-22.6$ & $10.9-18.4-20.6$ & \\
\hline Xylem vessels & & & $19.2-40-55$ & \\
\hline Xylem parenchyma & $31.4-90.3-116$ & $17.4-26.2-37.2$ & & \\
\hline Tracheids & $126-209-236$ & $13.5-20.4-26.7$ & & \\
\hline Fibrotracheids & $116-275-452$ & $6.8-18.8-31.7$ & & \\
\hline Starch granules & & Range from 3.5 & .7 micrometer & \\
\hline
\end{tabular}

\section{2) The primary axis (Primary rachis)}

A transverse section in the primary rachis is nearly triangular in outline (Fig. 17A\&B). It shows single row of an outer epidermal cells. The ground tissues are composed of parenchymatous hypodermis, interrupted with several hypodermal strands of lignified sclerenchymatous fibers, followed by several layers of thin walled parenchymatous cells. The endodermis and the pericylce are not distinct. The stele is of atactostele type in which many closed vascular bundles are irregularly scattered in the ground tissue.

\section{The epidermis}

In transverse section (Fig. 18A\&B) it is composed of one row of square to subrecangular cells and covered with thin smooth cuticle, hairs are absent.

\section{The ground tissue}

The detailed sector (Fig. 18) shows an outer parenchymatous hypodermis almost one layer followed by wide cortex interrupted with numerous strands of sclerenchymatous fibers in the upper part. The remaining ground tissue consists of several rows of oval to rounded thin walled parenchymatous cells showing wide intercellular spaces and contains starch granules, raphides of $\mathrm{Ca} \mathrm{Ox}$. and many closed vascular bundles scattered in the ground with nearly rounded shape.

\section{The vascular bundles (Figs. 17\&18)}

The vascular bundles are of atactostele type, scattered in the ground parenchyma, the peripheral ones are with small xylem vessels and phloem but with massive sheath of sclerencymatous fibers surrounding it, while the inner bundles are wide with usually two wide xylem vessels and phloem tissues consisting of sieve tubes and companion cells.

Powder (Figs. 19\&20) \& (Table 2)

1- Fragments of the epidermal cells in surface view that are similar to that of lower epidermis of leaf but with more rectangular to sub rectangular shape with numerous dumbbell shape stomata.

2- Fragments of needle crystals of Ca.ox either free or usually in bundles to form raphides sacs.

3- Fragments of tracheids that are adjacent to fibrotracheids, both are lignified, with thick walls and wide lumen, containing numerous small pits, but the fibrotracheids have one tapering end.

4- Fragments of fibrotracheids that have one broad end and other tapering one, with thick lignified walls and moderately wide lumen containing numerous pits.

5- Fragments of tracheids with thick lignified walls and wide lumen containing numerous small pits.

6- Fragments of spindle shape pericyclic fibers with narrow lumen and moderately thick lignified walls and tapering acute apex.

7- Fragments of lignified xylem vessels having simple pitted, spiral or scalariform thickening.

8- Fragments of wood parenchyma having rectangular to subrectangular shapes, with thick lignified walls, having usually moderately wide Lumina and numerous pits. 


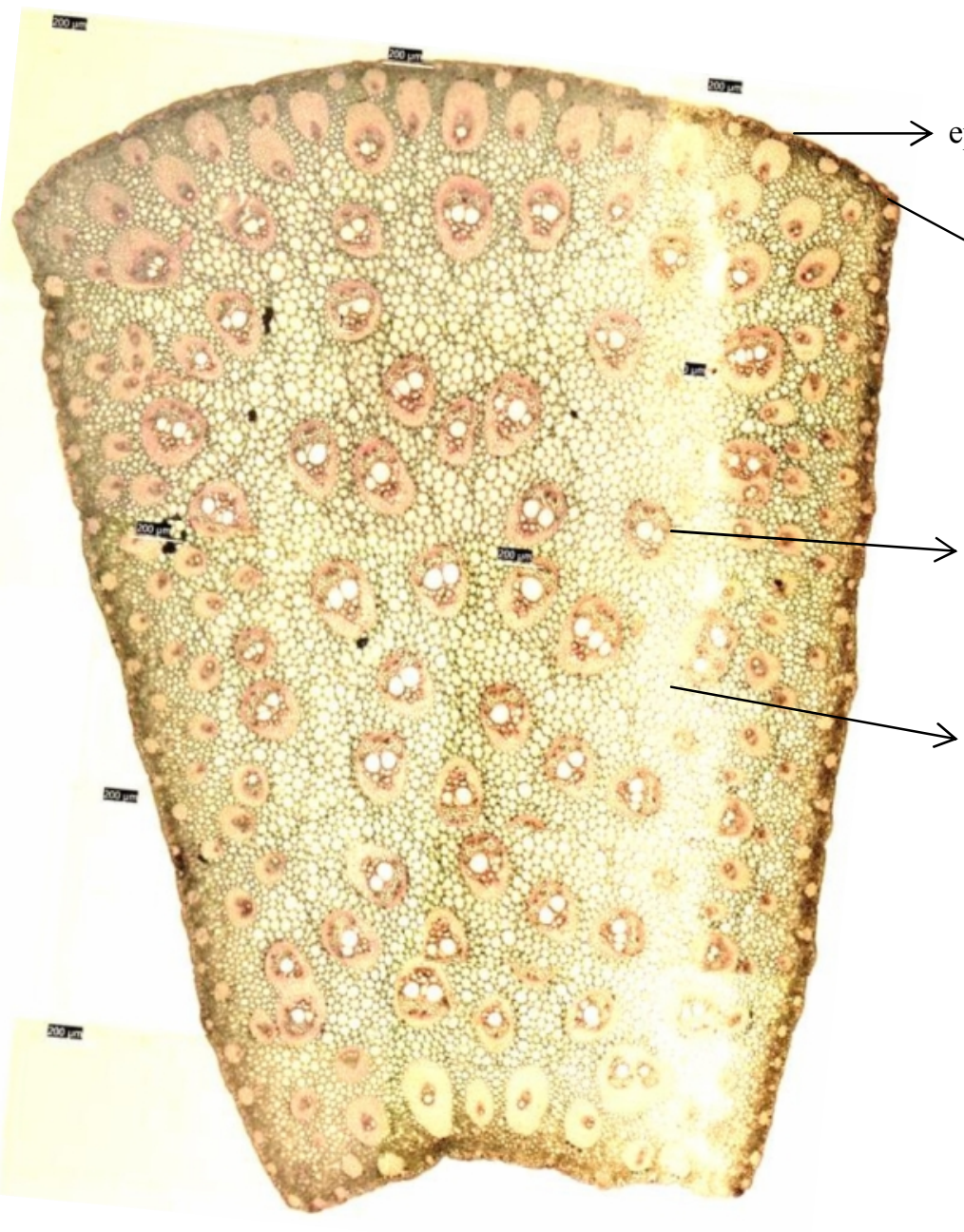

A

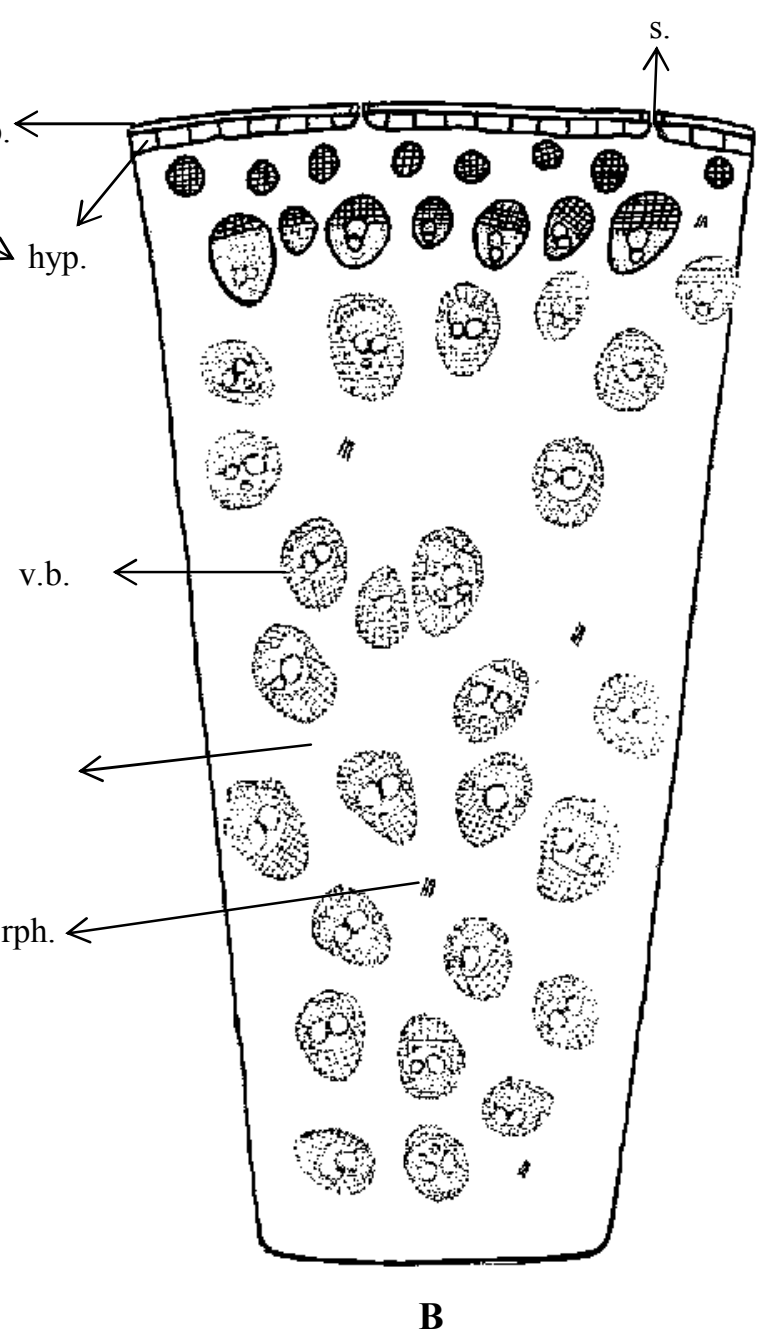

Fig. 17: A- Photo of T.S. diagram in the primary axis.

B- Diagramatic T.S. in the primary axis.

$(\mathrm{X}=40)$

ep., epidermis; gr. t., ground tissue; hyp., hypodermis; rph., raphides of Ca.Ox.; s., stomata; v.b., vascular bundle. 


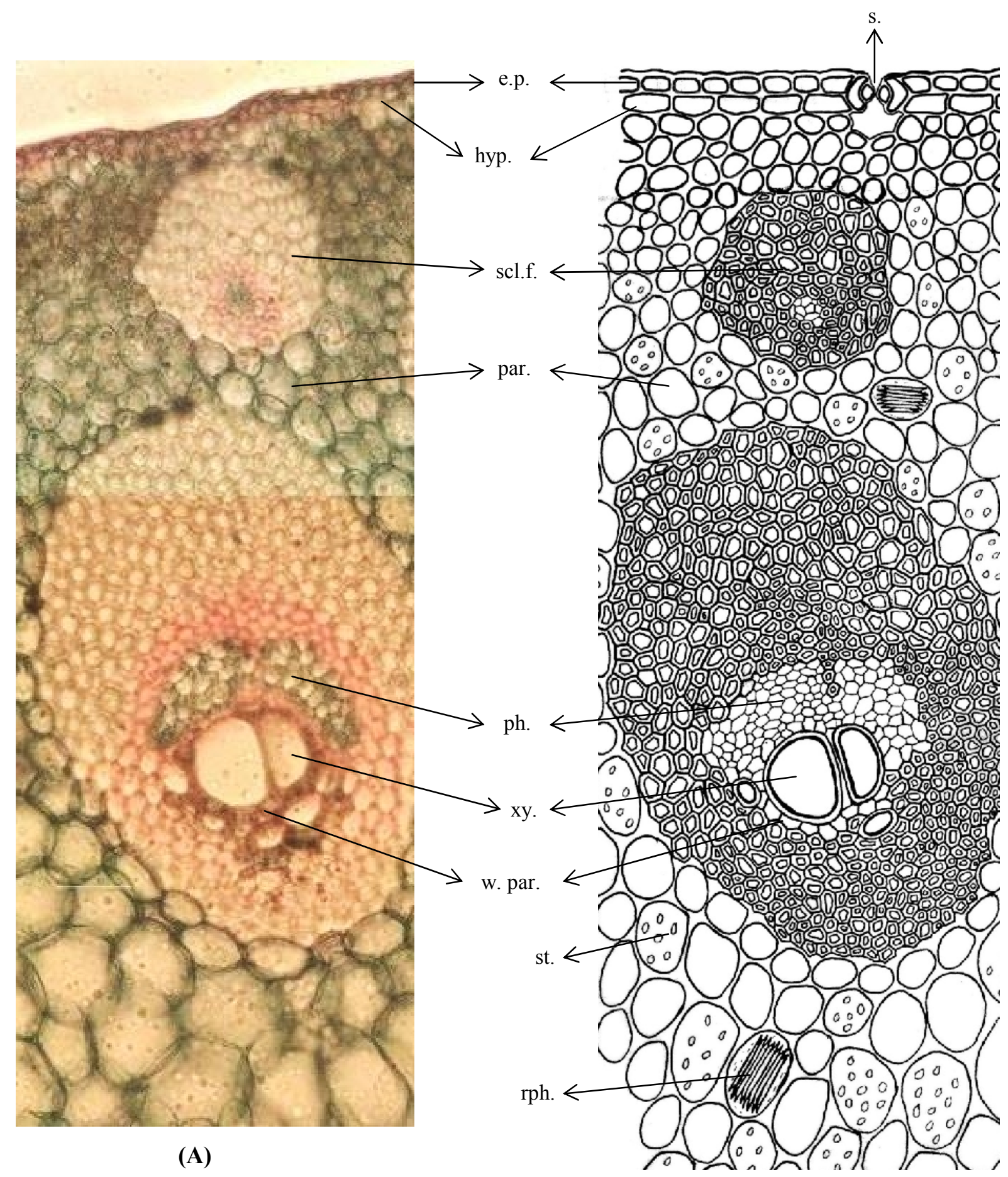

(B)

Fig. 18: A- Photo of T.S. detailed in the peimary axis.

$(\mathrm{X}=200)$

B- T.S. detailed in the primary axis.

$(\mathrm{X}=200)$

ep., epidermis; hyp., hypodermis; par., parenchyma; ph., phloem; rph., raphides of Ca.Ox.; s., stomata; scl. f., sclerenchymatous fibers; st., starch granules; w. par., wood parenchyma; xy., xylem vessel. 

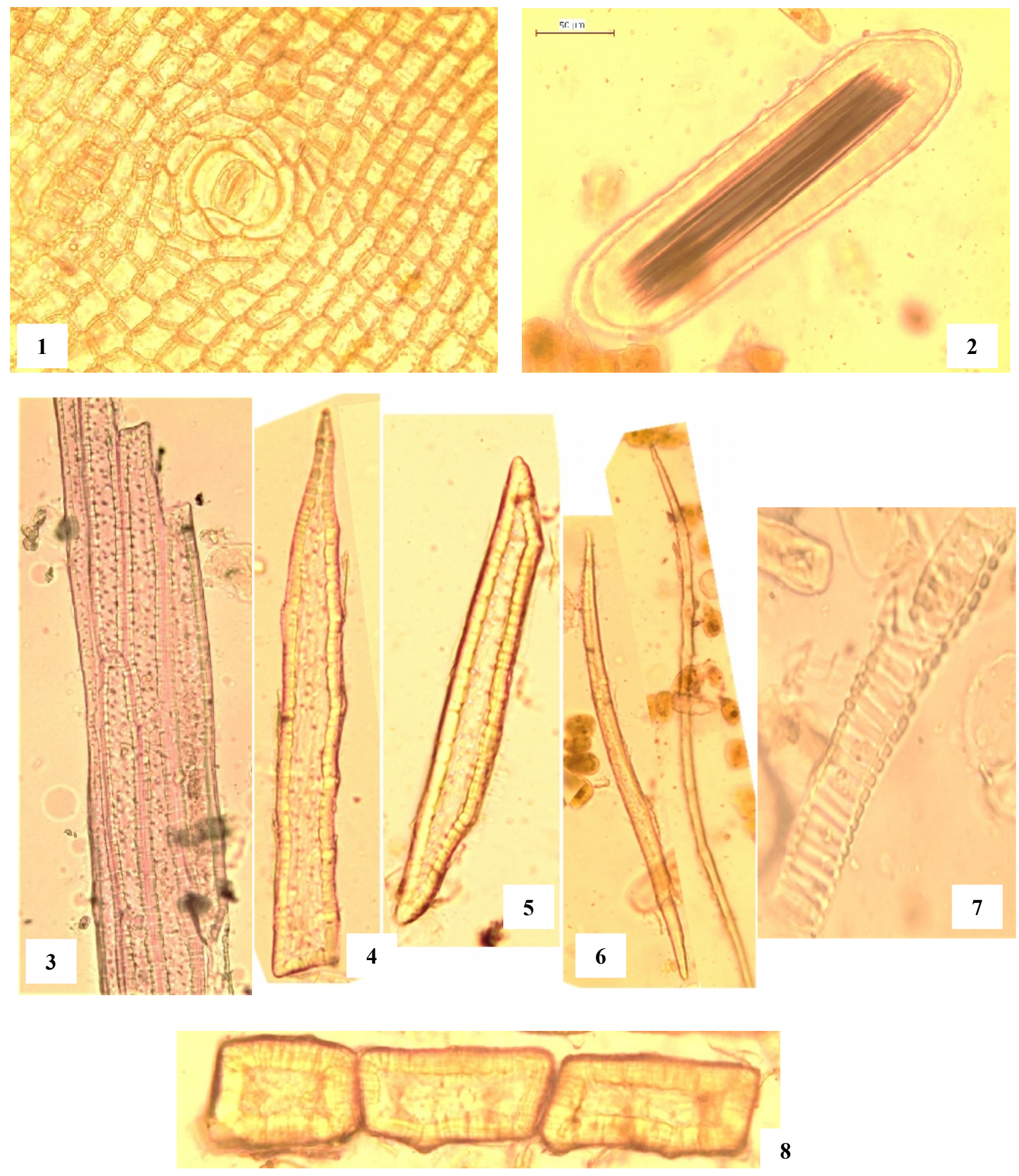

Fig. 19: Powder and isolated elements of primary axis.

$(X=200)$

$\mathbf{1}$, epidermal cells; $\mathbf{2}$, raphidesof Ca.Ox; $\mathbf{3}$, fibrotracheids adjacent to tracheids; $\mathbf{4}$, tracheideal fiber; $\mathbf{5}$, tracheid; $\mathbf{6}$, pericyclic fiber; 7 , xylem vessels; 8 , wood parenchyma. 

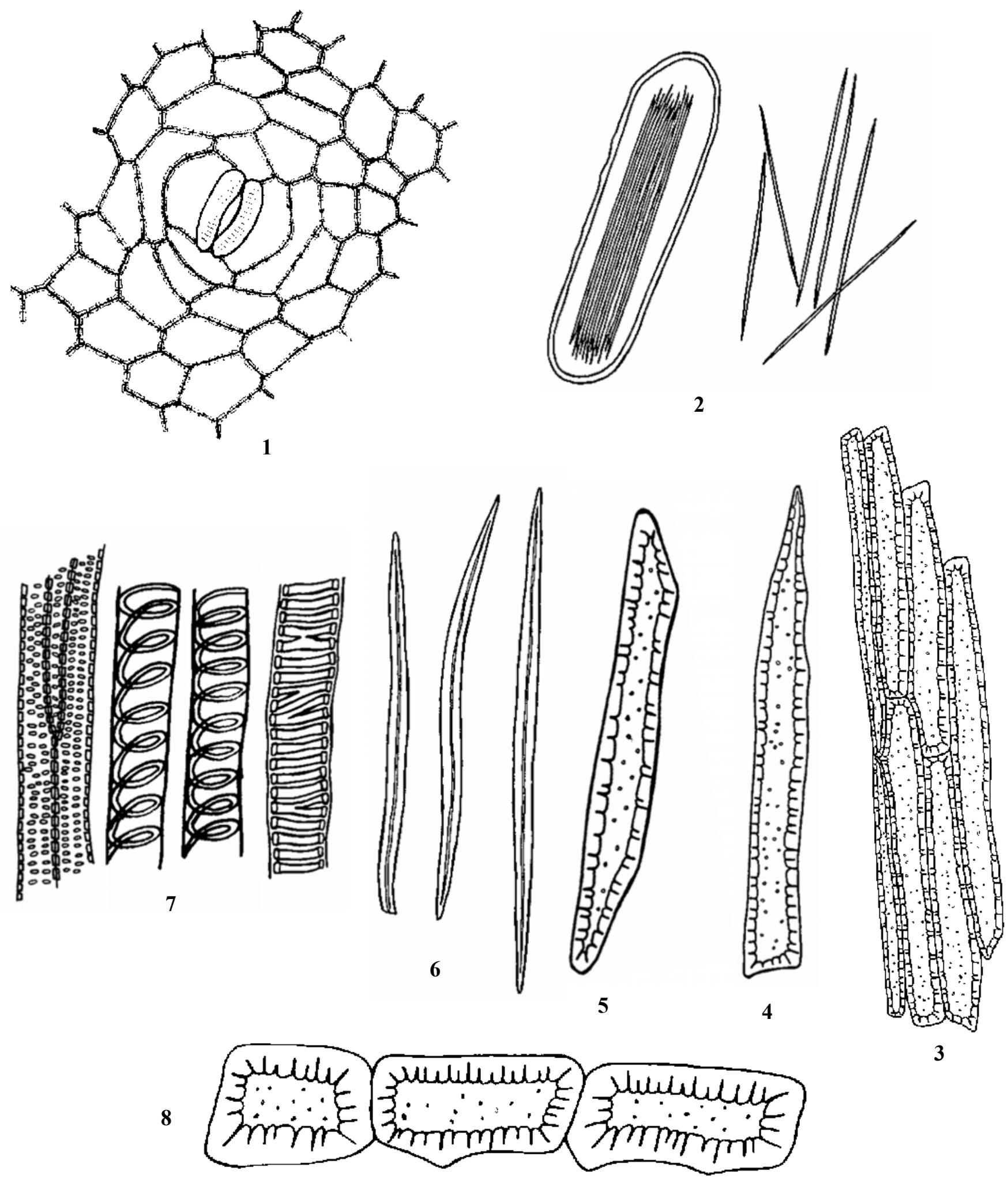

Fig. 20: Powder and isolated elements of primary axis.

$(\mathrm{X}=200)$

1, epidermal cells; $\mathbf{2}$, raphidesof Ca.Ox; $\mathbf{3}$, fibrotracheids adjacent to tracheids; $\mathbf{4}$, tracheideal fiber; $\mathbf{5}$, tracheid; $\mathbf{6}$, pericyclic fiber; $\mathbf{7}$, xylem vessels; 8 , wood parenchyma. 
Table 2: Microscopical measurements of the primary axis of $C$. mitis Lour. (in microns).

\begin{tabular}{||l|c|c|c|c||}
\hline \multicolumn{1}{||c|}{ Item } & Length & Width & Diameter & Height \\
\hline \multicolumn{5}{|c||}{ Primary axis } \\
\hline Neural epidermis & $9.6-19.7-33$ & $11.86-16.78-21$ & & \\
\hline Hypodermis & & & $17.6-\underline{-29.2-43.4}$ & $9.51-14.9-22.7$ \\
\hline Stomata & $26.6-\underline{31.3}-43.8$ & $42.2-\underline{56.1-61.7}$ & & \\
\hline Parenchyma & & & $25.6-\underline{38.4-50.8}$ & \\
\hline Chlorenchyma & & & $6.9-11.3-15.5$ & \\
\hline Acicular Ca Ox. & $180-\underline{194}-221$ & & & \\
\hline Pericyclic fibres & $353-\underline{594}-893$ & $10.7-\underline{13.6}-20.4$ & & \\
\hline Xylem vessels & & & $14.8-\underline{41.6}-59$ & \\
\hline Xylem parenchyma & $26.3-\underline{81.9-124}$ & $20.4-\underline{31.2}-43.5$ & & \\
\hline Tracheids & $136-\underline{227-251}$ & $15.7-\underline{23.5}-27.9$ & & \\
\hline Fibrotracheids & $133-291-439$ & $7.3-21.4-33.1$ & & \\
\hline \hline
\end{tabular}

\section{III- Biological activities}

\section{a) Determination of $\mathbf{L D}_{50}$}

Specific weights of the different extracts of the leaves were suspended in saline solution by the aid of tween $80(3 \% \mathrm{v} / \mathrm{v})$ and the volume was completed to $20 \mathrm{ml}$ with saline solution.

Different dose levels $(100-5000 \mathrm{mg} / \mathrm{kg})$ of each extract ofCaryota mitis were intraperitoneally injected in different groups of mice according to the reported method ${ }^{8}$. For each extract, we used 18 albino mice which are classified into six homogenous groups, each composed of three animals. Each group was held in a separate cage. The animals received gradual increasing doses of the tested extracts in a saline solution by intraperitoneal injection. With each test, a parallel control group was given the saline by intraperitoneal injection in the same volume as the tested groups. All animals were kept under a constant observation for six hours for the appearance of the signs of toxicity or any change in the general behavior or other physiological activities. Mortality in each group was recorded 24 hours after fraction administration.

\section{b) Evaluation of the anti-inflammatory, antipyretic and analgesic activities \\ Anti-inflammatory assay}

Carrageenin-induced rat hind paw oedema model described by Winter et al. ${ }^{9}$ was performed. The pedal inflammation was induced in rat paws of eight groups (6 rats/ group) by injection of $0.1 \mathrm{ml}, 1 \%$ carageenan suspension in $0.9 \% \mathrm{NaCl}$ solution into the subplantar tissue of the right hand paw. At the beginning of the experiment, the paws thickness was measured in mm using varinier caliber. The first group was kept as a negative control, injected intraperitoneally by $2 \%$ tween 80 in normal saline while the second group injected by indomethacin $(8 \mathrm{mg} / \mathrm{Kg})$ as a positive control. The other groups were separately intraperitioneally injected with the different fractions of the leaves at a dose of 400 $\mathrm{mg} / \mathrm{kg}$ of the body weight. After 30 minutes from administration, the inflammation was induced by injection of the carrageenan suspension in the right paw while the left one was injected by an equal volume of saline solution. The difference between the thicknesses of the two paws was taken as a measure of edema. The anti-inflammatory efficacy of the tested fractions was estimated by comparing the magnitude of paw swelling in the pretreated animals with those induced by in control animals receiving saline. The measurements were carried out at 1,2,3,4 and $5 \mathrm{hrs}$ after injection of the inflammatory agent. The percentage of inhibition was calculated as follows:

$$
\begin{aligned}
& \% \text { variation }(\text { edema })= \\
& \frac{(\text { right paw thickness }- \text { left paw thickness })}{\text { left paw thickness }} X 100
\end{aligned}
$$$$
\% \text { inhibition }=\frac{\left(V_{o}-V_{t}\right) \times 100}{V_{o}}
$$

$\mathrm{V}_{\mathrm{o}}=$ The average paw thickness of the control group. $V_{t}=$ The average paw thickness of the treated group.

The results of the measurements of the paw thickness and percentage antinflammatory activity are listed in tables $3 \& 4$, respectively. 
Table 3: Effect of different extracts of $C$. mitis leaves on the right hind paw thickness in carrageenin induced hind paw oedema model in rats.

\begin{tabular}{|c|c|c|c|c|c|c|c|}
\hline \multirow{3}{*}{ Group } & \multirow{3}{*}{$\begin{array}{c}\text { Dose } \\
\text { (mg / } \\
\text { kg) }\end{array}$} & \multicolumn{6}{|c|}{ Time after phlogistic agent administration (hour) } \\
\hline & & 0.5 & 1 & 2 & 3 & 4 & 5 \\
\hline & & \multicolumn{6}{|c|}{ Thickness of the right hind paw (mm) } \\
\hline Negative control & & $7.82 \pm 0.173$ & $7.78 \pm 0.283$ & $7.78 \pm 0.199$ & $7.71 \pm 0.325$ & $7.68 \pm 0.310$ & $7.68 \pm 0.295$ \\
\hline Indomethacin & 8 & $5.72 \pm 0.054$ & $4.94 \pm 0.118$ & $4.34 \pm 0.185$ & $4.2 \pm 0.076$ & $4.5 \pm 0.129$ & $4.95 \pm 0.133$ \\
\hline Total Extract & 400 & $6.2 \pm 0.234$ & $5.09 \pm 0.161$ & $4.63 \pm 0.277$ & $6.17 \pm 0.118$ & $6.34 \pm 0.233$ & $7.19 \pm 0.131$ \\
\hline$n$-Hexane fr. & 400 & $6.88 \pm 0.073$ & $5.24 \pm 0.171$ & $4.57 \pm 0.223$ & $5.24 \pm 0 . .069$ & 6. $9 \pm 0.179$ & $7.31 \pm 0.323$ \\
\hline Chloroform fr. & 400 & $6.16 \pm 0.135$ & $5.65 \pm 0.059$ & $5.29 \pm 0.149$ & $5.53 \pm 0.228$ & $6.79 \pm 0.108$ & $7.22 \pm 0.192$ \\
\hline Ethyl acetate fr. & 400 & $6.51 \pm 0.327$ & $6.03 \pm 0.161$ & $5.46 \pm 0.098$ & $5.98 \pm 0.085$ & $6.58 \pm 0.175$ & $7.12 \pm 0.187$ \\
\hline$n$-butanol fr. & 400 & $6.95 \pm 0.111$ & $6.11 \pm 0.252$ & $6.45 \pm 0.259$ & $6.47 \pm 0.345$ & $7.62 \pm 0.246$ & $7.64 \pm 0.314$ \\
\hline Aqueous fr. & 400 & $5.67 \pm 0.244$ & $4.58 \pm 0.165$ & $4.46 \pm 0.331$ & $5.53 \pm 0.127$ & $5.63 \pm 0.248$ & $5.78 \pm 0.165$ \\
\hline
\end{tabular}

Data are expressed as mean \pm S.E, $n=6$.

Table 4: Percentage anti-inflammatory activity of the different extracts of $C$. mitis leaves on carrageenin-induced hind paw edema model in rats.

\begin{tabular}{|c|c|c|c|c|c|c|c|}
\hline \multirow{3}{*}{ Group } & \multirow{3}{*}{$\begin{array}{c}\text { Dose } \\
(\mathrm{mg} / \mathrm{kg})\end{array}$} & \multicolumn{6}{|c|}{$\begin{array}{c}\text { Time after phlogistic agent administration } \\
\text { (hours) }\end{array}$} \\
\hline & & 0.5 & 1 & 2 & 3 & 4 & 5 \\
\hline & & \multicolumn{6}{|c|}{$\%$ inhibition of inflammation } \\
\hline Indomethacin & 8 & 26.85 & 36.75 & 44.21 & 45.52 & 41.4 & 35.54 \\
\hline Total EtOH extract & 400 & 20.71 & 34.57 & 40.48 & 19.97 & 17.44 & 6.38 \\
\hline$n$-Hexane fr. & 400 & 12.02 & 32.64 & 41.25 & 32.03 & 10.15 & 4.81 \\
\hline Chloroform fr. & 400 & 21.22 & 27.37 & 32 & 28.27 & 11.58 & 5.98 \\
\hline Ethyl acetate fr. & & 16.75 & 22.49 & 29.82 & 22.43 & 14.32 & 7.29 \\
\hline$n$-Butanol fr. & 400 & 11.12 & 21.46 & 17.09 & 16.08 & 0.76 & 0.52 \\
\hline Aqueous fr. & 400 & 27.49 & 41.13 & 42.67 & 28.27 & 26.29 & 24.73 \\
\hline
\end{tabular}

\section{Antipyretic activity assay}

Yeast induced hyperthermia in rats described by Hernández-Pérez et al. ${ }^{10}$ was performed. Eight groups of (6 rats/group) were used and the rectal temperature was recorded with a thermometer. Hyperthermia was induced at first by subcutaneous injection $20 \%(\mathrm{w} / \mathrm{v})$ aqueous suspension of yeast in a volume of 10 $\mathrm{ml} / \mathrm{kg}$. The first group was kept as a negative control injected intraperitoneally by $2 \%$ tween
80 in 0.9 normal saline. While the second group injected by indomethacine $(8 \mathrm{mg} / \mathrm{kg})$ as a positive control. The other groups were separately injected intraperitoneally with the different fractions at doses of $400 \mathrm{mg} / \mathrm{kg}$ body weight. Rectal temperatures were taken after 1 , 2, 3, 4 and $5 \mathrm{hrs}$ from administration of tested fractions. The results of the measurements of rectal temperatures are listed in table 5 . 
Table 5: Effect of different extracts of $C$. mitis L. leaves on yeast induced fever in rats.

\begin{tabular}{|c|c|c|c|c|c|c|}
\hline \multirow{3}{*}{ Group } & \multirow{3}{*}{$\begin{array}{c}\text { Dose } \\
(\mathrm{mg} / \mathrm{kg})\end{array}$} & \multicolumn{5}{|c|}{ Time (hour) } \\
\hline & & 1 & 2 & 3 & 4 & 5 \\
\hline & & \multicolumn{5}{|c|}{ Rectal temperature } \\
\hline Negative control & & $39.76 \pm 0.051$ & $39.67 \pm 0.322$ & $39.63 \pm 0.103$ & $39.50 \pm 0.206$ & $39.3 \pm 0.136$ \\
\hline Indomethacin & 8 & $37.06 \pm 0.136$ & $36.4 \pm 0.179$ & $36.23 \pm 0.372$ & $36.57 \pm 0.338$ & $36.87 \pm 0.136$ \\
\hline Total Extract & 400 & $37.81 \pm 0.192$ & $37.67 \pm 0.206$ & $37.33 \pm 0.115$ & $38.76 \pm 0.273$ & $39.10 \pm 0.225$ \\
\hline n-Hexane fr. & 400 & $37.70 \pm 0.268$ & $37.45 \pm 0.134$ & $37.14 \pm 0.178$ & $37.97 \pm 0.186$ & $38.90 \pm 0.178$ \\
\hline Chloroform fr. & 400 & $38.03 \pm 0.136$ & $37.42 \pm 0.125$ & $37.40 \pm 0.205$ & $38.40 \pm 0.261$ & $39.13 \pm 0.128$ \\
\hline Ethyl acetate fr. & 400 & $37.67 \pm 0.361$ & $37.27 \pm 0.287$ & $38.20 \pm 0.357$ & $38.67 \pm 0.225$ & $38.93 \pm 0.225$ \\
\hline n-Butanol fr. & 400 & $37.87 \pm 0.225$ & $37.12 \pm 0.240$ & $37.50 \pm 0.301$ & $38.71 \pm 0.281$ & $39.13 \pm 0.403$ \\
\hline Aqueous fr. & 400 & $37.60 \pm 0.089$ & $37.30 \pm 0.089$ & $37.17 \pm 0.186$ & $37.20 \pm 0.089$ & $37.53 \pm 0.136$ \\
\hline
\end{tabular}

Data are expressed as mean \pm S.E, $n=6$

Table 6: The results of analgesic activities of the different extracts of the leaves of C. mitis by acetic acid-induced writhing in rats:

\begin{tabular}{|l|c|c|c||}
\hline \multicolumn{1}{|c|}{ Group } & $\begin{array}{c}\text { Dose } \\
\text { (mg/kg) }\end{array}$ & $\begin{array}{c}\text { Mean No. of writhes } \pm \\
\text { SEM }\end{array}$ & $\begin{array}{c}\text { \% } \\
\text { inhibition }\end{array}$ \\
\hline Negative control & & $77 \pm 5.03$ & ------ \\
\hline Ketoprofen & 10 & $6.75 \pm 1.25$ & 91.23 \\
\hline Total extract & 400 & $3 \pm 0.82$ & 96.1 \\
\hline$n$-Hexane fr. & 400 & $20 \pm 2.82$ & 74.02 \\
\hline Chloroform fr. & 400 & $12 \pm 1.63$ & 84.41 \\
\hline Ethyl acetate fr. & 400 & $5.5 \pm 4.43$ & 92.85 \\
\hline Ethanol fr. & 400 & $27.5 \pm 4.43$ & 64.28 \\
\hline Aqueous fr. & 400 & $37 \pm 3.82$ & 51.94 \\
\hline
\end{tabular}

Data are expressed as mean \pm S.E, $n=6$

\section{Analgesic activity}

The analgesic activity was evaluated by the acetic acid-induced writhing in mice $^{11}$. Different groups of 4 rats each received IP normal saline solution $(10 \mathrm{ml} / \mathrm{kg})$ (control), ketoprofen $(10 \mathrm{mg} / \mathrm{kg})$, or total ethanolic extract, n-hexane, dichloromethane, ethyl acetate, $n$-butanol and aqueous fractions at a dose of $400 \mathrm{mg} / \mathrm{kg}$. Thirty minutes later, $0.7 \%$ acetic acid $(10 \mathrm{ml} / \mathrm{kg})$ solution was injected intraperitoneally to the all animals in the different groups. The number of writhes (abdominal constrictions) occurring between 5 and $20 \mathrm{~min}$ after acetic acid injection was counted. A significant reduction of number of writhes in the control group was considered as an analgesic effect. The percentage of inhibition is calculated using the following ratio:

\footnotetext{
$\%$ inhibition $=$

Mean No. of writhes (control)-Mean No. of writhes (test) $X 100$ Mean No. of writhes (control)
}

The results of central analgesic activities of the different extracts of the leaves of $C$. mitis leaves on acetic acid-induced writhing in mice are listed in table 6 . 


\section{DISCUSSION}

From the data above, it is clear that no mice were died in all doses of $C$. mitis extracts during the $\mathrm{LD}_{50}$ experiment up to $5000 \mathrm{mg} / \mathrm{kg}$, and this indicates the saftey of all fractions of the plant.The anti-inflammatory effect of the different extract (Tables $3 \& 4$ ) begins within the first hour becoming highly significant in the 2nd and 3rd hours and continue till the 5th hour. The aqueous fraction showed the highest percentage of anti-inflammatory activity while the n-butanol fraction showed the least percentage of anti-inflammatory activity. Also, by analysis of the obtained results (Table 4), $n$ hexane and aqueous fractions exhibited significant antipyretic activity against yeastinduced hyperthermia. The effect reached its maximum at the 3 rd hour and continued till the 5 th hour. Finally, results from table 5 indicate that all the tested extract showed varying significant analgesic activity. The total ethanolic extract and ethyl acetate fractions showed the higher percentage of inhibition than the other fractions.

\section{Conclusion}

Caryota mitis Lour. is an ornamental palm belongs to family Arecacea. Its leaflets are characterized morphologically by the characteristic fish tail appearance while micromorphologically by the presence of scattered closed vascular bundles that are surrounded by sclerotic cylinder of sclerenchymatous fibers. Numerous raphides of calcium oxalate are the main feature of the plant in powdered form. The biological study revealed that the plant leaves are safe exhibiting strong antioxidant and antimicrobial activity specially against gram positive bacteria, in addition to cosiderable antiinflamatory, antipyretic and analgesic activities.

\section{REFERENCES}

1. M. J. Christenhusz and J. W. Byng, "The number of known plants species in the world and its annual increase", Phytotaxa, 261 (3), 201-217 (2016).

2. P. B. Tomlinson, "Anatomy of the Monocotyledons", II. Palmae, 1961, pp. 168-171.

3. D. S. Snyder, G. M. Hatfield and K. F. Lampe, "Examination of the itch response from the raphides of the fishtail palm Caryota mitis.", Toxicol. Appl. Pharmacol., 48 (2), 287-92 (1979).

4. A. Charles, M. Joseph and V. A. Ramani, "Quanttitative estimation of primary and secondary metabolites on flowers of Caryota urens. L.", Int. J. Appl. Bio. Pharm., 2 (3), 331-335 (2011).

5. M. Sharief, "Plants folk medicine of Negrito tribes of Bay Islands", Indian J. Tradit. Know., 6 (3), 468-476 (2007).

6. A. H. Mollik, A. I. Hassan, T. K. Paul, M. Sintaha, H. N. Khaleque, F. A. Noor, et al., "A survey of medicinal plant usage by folk medicinal practitioners in two villages by the Rupsha River in Bagerhat district, Bangladesh", Am.-Eurasian J. Sustain Agric., 349-57 (2010).

7. P. Shengji, C. Sanyang, G. Lixiu and A. Henderson, "Arecaceae (Palmae)", Flora of China, 23, 132-157 (2010).

8. D. Lorke, "A new approach to practical acute toxicity testing", Arch. Toxicol., 54 (4), 275-287 (1983).

9. C. A. Winter, E. A. Risley and G. W. Nuss, "Anti-inflammatory and antipyretic activities of indo-methacin, 1-(pchlorobenzoyl)-5-methoxy-2-methylindole-3-acetic acid", J. Pharmacol. Exp. Ther., 141 (3), 369-376 (1963).

10. M. Hernández-Pérez, R. M. Rabanal, M. C. de la Torre and B. Rodríguez, "Analgesic, anti-inflammatory, antipyretic and haematological effects of aethiopinone, an o-naphthoquinone diterpenoid from Salvia aethiopis roots and two hemisynthetic derivatives", Planta Medica, 61 (06), 505-509 (1995).

11. R. Koster, M. Anderson and E. De Beer, editors, "Acetic acid-induced analgesic screening", Fed. Proc., 18, 412 (1959). 
دراسة نباتية وبيولوجية لآوراق نخيل ذيل السمكة المنتمي للعائلة الفوفلية

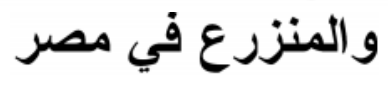

إسلام عادل عبد الحكيم - عفاف محمد عبد الباقي - داوود ونيس بشاي

قسم العقاقير ، كلية الصيدلة ، جامعة أسيوط ، أسيوط ، مصر

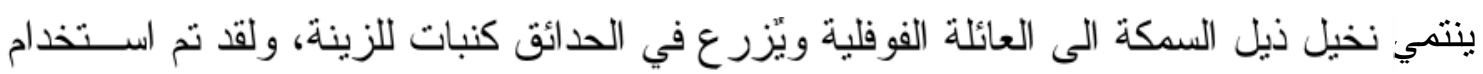

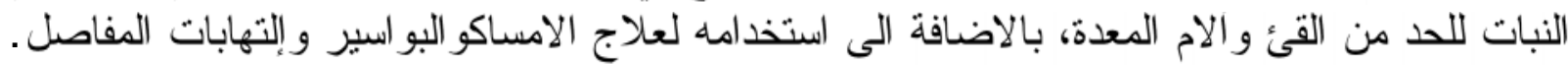

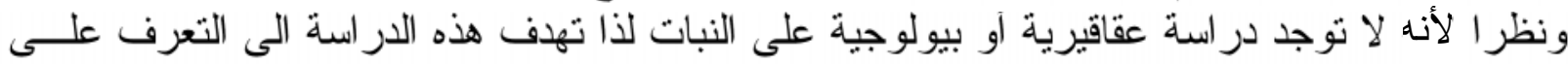

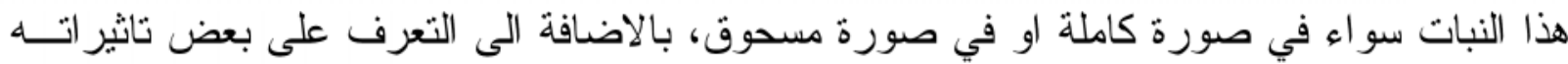

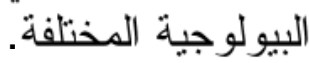

